\title{
REPORT ON THE FIRST STAGE OF THE IRON AGE DATING PROJECT IN ISRAEL: SUPPORTING A LOW CHRONOLOGY
}

\author{
Ilan Sharon ${ }^{1}$ • Ayelet Gilboa ${ }^{2}$ A J Timothy Jull ${ }^{3}$ Elisabetta Boaretto ${ }^{4}$ \\ ABSTRACT. The traditional chronology of ancient Israel in the 11th-9th centuries BCE was constructed mainly by corre- \\ lating archaeological phenomena with biblical narratives and with Bible-derived chronology. The chronology of Cyprus and \\ Greece, and hence of points further west, are in turn based on that of the Levant. Thus, a newly proposed chronology, about \\ 75-100 yr lower than the conventional one, bears crucial implications not only for biblical history and historiography but also \\ for cultural processes around the Mediterranean. A comprehensive radiocarbon program was initiated to try and resolve this \\ dilemma. It involves several hundreds of measurements from 21 sites in Israel. Creating the extensive databases necessary for \\ the resolution of tight chronological problems typical of historical periods involves issues of quality control, statistical treat- \\ ment, modeling, and robustness analysis. The results of the first phase of the dating program favor the new, lower chronology.
}

\section{INTRODUCTION}

The construction of an "Old World chronology" of the Bronze and Iron ages (4th-1st millennia BCE) was one of the major intellectual achievements of the late 19th-early 20th centuries. However, it was a complicated web, spun out of snippets of contemporary information, inlaid in a mesh of later-written (hi)stories of varying credibility and agenda. It was synchronized by linking archaeological finds and phenomena across different, often faraway regions, and pegged to an absolute time scale by a few ancient astronomical observations, the understanding of which is in dispute (cf. Ward 1992). Recent years have seen crushing critiques of these, some even of the web in its entirety (e.g. James et al. 1992). There is an increasing call to bolster this chronology, if not altogether replace it, with scientifically derived chronometry, namely ${ }^{14} \mathrm{C}$ and dendrochronology (Renfrew 1991).

Several major projects launched in the last decade aim to do just that-at different geographical areas and historical periods. Some Old World examples are The Aegean Dendrochronology Project (www.arts.cornell.edu/dendro/); dating the Early Bronze Age in the Ancient Near East (the ARCANE project; www.arcane.uni-tuebingen.de); 2nd millennium chronology around the Mediterranean (the SCIEM project, see www.sciem2000.info/Pr05main.html); the date of the Thera eruption and its repercussions (e.g. Manning et al. 2006 with further bibliography there); dating the end of the Late Bronze Age (e.g. Manning et al. 2001); the Italian Iron Age (Nijboer et al. 2001); and dating the Phoenician and Greek colonization of the western Mediterranean (e.g. Torres Ortiz 1998; Botto 2004; Mederos Martín 2005).

Indeed, trying to resolve the chronological sequence of social, economic, and political processes that interest historians and archaeologists of historical periods is a challenge for the radiocarbon method, as they require much higher resolution than do longue durée processes typically studied by prehistorians and geologists. Working so close to the limit of precision of the analytic technique requires first of all very large data sets and also the development of rigorous protocols for quality controlin the field and in the laboratory - and of the statistical treatment of the results. Such measures, should they prove effective, could open new horizons for the collaboration between archaeologists, historians, and physicists.

\footnotetext{
${ }^{1}$ Institute of Archaeology, Hebrew University, Jerusalem, Israel. Corresponding author. Email: Sharon@mscc.huji.ac.il.

${ }^{2}$ Zinman Institute of Archaeology, University of Haifa, Israel.

${ }^{3}$ NSF-Arizona AMS Facility, University of Arizona, Tucson, Arizona.

${ }^{4}$ Radiocarbon Dating and Cosmogenic Isotopes Laboratory, Weizmann Institute of Science, Rehovot, Israel.
} 


\section{THE ARCHAEOLOGICAL/HISTORICAL PROBLEM}

In the late 13th/early 12th centuries BCE, the Late Bronze Age sociopolitical systems in the Aegean and the eastern Mediterranean collapsed (e.g. Ward et al. 1992). The disappearance of these administrations means an almost total lack of contemporary written sources and of epigraphic finds in clear archaeological associations, which renders impossible direct historical dating of the following centuries (12th-9th centuries BCE).

Ancient Israel was until recently considered an exception. The deeds of its kings were recorded in the Bible, and dated by biblical king lists. Archaeologists associated constructions and destructions in the relevant sites with the biblical record and thus obtained dates for pottery assemblages associated with these "events." Comparative cross-dating with such "biblical" strata is a major peg upon which the early Iron Age chronology of the Levant, Cyprus, Greece, and even regions farther afield is largely dependent (see summary and references in Gilboa and Sharon 2003:64-72). Any shift in the former would entail re-adjustments of all these chronological constructions, and dictate rethinking of nearly every early Iron Age cultural process in these regions (e.g. Fantalkin 2001; Gilboa and Sharon 2001, 2003; Kopcke 2002; Coldstream 2003; Mederos Martín 2005).

However, in Israel too, pegs of absolute chronology are nonexistent for these centuries. Archaeologically, the Iron Age in Israel/Palestine is roughly divided into 2 segments, based mainly on the occupational sequence in the Central Hill country: "Iron I," in which the highlands were apparently settled by egalitarian rural societies; and "Iron II," which displays in this region phenomena customarily equated with a state system (settlement hierarchy, fortified administrative centers, and the like). Turning to the historical scenario as portrayed in the Bible, especially the "Deuteronomistic History" (the books of Deuteronomy through Kings; cf. for example, Knoppers and McConville 2000), it was only natural to associate "Iron I" with the tribal society described in Joshua-Judges, and to start "Iron II" with the United Monarchy of David and Solomon. Using the biblical king lists and "dead reckoning" from Assyrian, Babylonian, and Persian synchronisms at the end of the Iron Age, the Iron Age I|II transition—-the beginning of David's reign—should fall somewhat before 1000 BCE. More specifically, the terminus ante quem for the "Iron I"| "Iron II" transition is customarily placed at 980 BCE (e.g. Mazar 1990: chapter 8). This was based on the assumption that the destructions typifying late Iron I sites were caused by this monarch's conquests, and that subsequent reconstruction should be attributed to the building projects of Solomon. The expansion of David's kingdom started, according to biblical narratives, before his 7th year and concluded well before the end of his 40-yr reign (about $970 \mathrm{BCE}$ ), when he is portrayed as ailing, elderly, and contending with civil unrest and palace intrigue.

Since the 1970s, the historical validity of the relevant biblical narratives has increasingly been questioned, contending, inter alia, that the Israelite "United Monarchy" is a socially/politically motivated construct of much later periods (e.g. Thompson 1999; and see summary and critique in Dever 2001:23-52). The controversy spilled over into archaeology when it was suggested that the Iron Age I|II transition be lowered from about 1000/980 to 925/920 BCE (Finkelstein 1996). This means that Iron Age IIA phenomena conventionally associated with David's and Solomon's United Monarchy post-date the reign of these kings by biblical reckoning. The 10th century, assigned by this chronology to the Iron Age I archaeological horizon, thus lacks clear material remains befitting an organized state, much less the Davidic/Solomonic empire described in the Bible.

The contention that the biblical portrayal of David's vast conquests and Solomon's wealth and power cannot be demonstrated archaeologically fed into a long-standing dispute in biblical studies between so-called "maximalists," scholars contending that the biblical narratives should be taken at 
face value unless manifestly contradicted by outside evidence, and "minimalists," whose basic stance is that no biblical text can be taken literally unless corroborated by an outside source. This generated a fierce debate, which soon captured popular interest and even acquired political and religious overtones (summarized in Dever 2001). Lacking an answer to the chronological dilemma, dramatically different histories of ancient Israel are being written (e.g. Dever 2001 vs. Finkelstein and Silberman 2001, 2006; for recent summaries of the debate, see Finkelstein 2005; Mazar 2005).

\section{PREVIOUS RESEARCH}

Until the mid-1990s, the use of ${ }^{14} \mathrm{C}$ dating for the Iron Age in the Levant (and elsewhere) has been sporadic. Since then, 2 major excavation projects in Israel produced extensive sequences of early Iron Age ${ }^{14} \mathrm{C}$ determinations.

The first to produce a substantive set of pertinent dates was the coastal site of Tel Dor. Twenty-two samples, mostly charcoal, measured by liquid scintillation decay counting (LSC) at the Radiocarbon Dating Laboratory, Weizmann Institute of Science in Rehovot, supported the Low Chronology, placing the Iron Age I|II transition in the early 9th century BCE (Sharon 2001; Gilboa and Sharon 2001; 2003). This "ultra low" data set was the first empirical demonstration that the Low Chronology cannot be brushed off.

Adherents of the High Chronology claimed that the Dor results were "ambiguous" and inconsistent, that the stratigraphy at Dor is "complicated," the periodization too detailed (Bruins et al. 2003:316; Coldstream and Mazar 2003: n.14; Mazar 2004:33-34; Mazar 2005: n.6), and therefore the entire typostratigraphic and chronological seriation scheme at Dor is erroneous. A detailed elucidation of the stratigraphy, pottery typology, and chronological scheme used at Dor and its chronological correlation to other regions in Israel and overseas was produced by Gilboa and Sharon (2003; cf. also Gilboa 1999a,b), and some further comments will be made below.

Criticism of the first Dor data set also included the allegation that the results produced at the Rehovot laboratory in the 1990s were biased (Mazar 2004:24; Mazar et al. 2005:252-253). To address the question of bias, we conducted, in the framework of the current program, an intercomparison exercise between the major laboratories involved: the Radiocarbon Dating and Cosmogenic Isotopes Laboratory, Weizmann Institute of Science in Rehovot (henceforward Rehovot); the NSF Arizona AMS Laboratory, University of Arizona, Tucson (henceforward, Tucson); and (to a more limited extent) the Center for Isotope Research at Groningen (henceforward Groningen). This comparison showed no systematic difference among the laboratories (Boaretto et al. 2005).

In addition, 9 more samples, from the same stratigraphical sequence at Dor that produced the 1990s dates, were measured in 2004/2005 at Rehovot and Tucson (Table 7: 4522, 4525, 4528, 4531, 4532, $4540,4541,4542,4556$ ), two of which were also dated at Groningen (Table 7: 4531, 4540). All were analyzed by accelerator mass spectrometry (AMS). This new Dor data set produces a slightly higher (though not significantly so) Iron Age I|II transition, about 900 BCE, which still unequivocally supports the Low Chronology and rejects the High one (Sharon et al. 2005:78-82). This corroborates our previous conclusions, which were based on the 1990s set.

Shortly afterwards, however, a second sequence consisting of 34 dates from the site of Tel Rehov in the Jordan valley was published, measured with gas proportional decay counting (GPC) and AMS at Groningen (Bruins et al. 2003). It was claimed by the Rehov investigators to prove an "amended high chronology." Maximalists were quick to embrace this data set as "the last nail in the coffin of the "low chronology"' (quotations from Holden 2003:229), while generally ignoring or belittling the contrary evidence. 
In reality, the Rehov "amended high" chronology goes a long way towards the contentions of the Low Chronology. The "amended high" chronology starts the Iron IIA at 980 BCE (the lowest possible date still compatible with biblical reckoning) but stretches it until about $830 \mathrm{BCE}$, contra the conventional view of ending it at 925 BCE (e.g. Bruins et al. 2003:318; Mazar 2004:30-31). Both the Dor and Rehov data sets corroborate that the Iron IIA horizon incorporates the 9th century BCE. The debate thus centers on the 10th century alone, or in other words, on the placement of the Iron I|II transition—at about 980 or about 900 ?

Critics of the Rehov data set claimed that the statistical procedures used in the original publication were flawed (Finkelstein and Piasetzky 2003; Sharon et al., forthcoming) and that the investigators ignored other dates from Tel Rehov, which were manifestly different. In response, the Rehov team also produced an augmented data set and an improved model supporting their view (Bruins et al. 2005; Mazar et al. 2005).

Can the Tel Rehov and Tel Dor dates be reconciled? It does need to be pointed out that Tel Rehov (as excavated to date) overrepresents Iron IIA. Detailed Iron IIA sequences in several excavation areas in this site produced abundant ceramic assemblages and organic remains, while Iron Age I strata are only exposed in a narrow step-trench on the slope. At Dor, the situation is reversed. Five horizons of superimposed Iron I (and I|II transition) were excavated in several different areas, while Iron IIA is underrepresented. This can go part way towards explaining the apparent contradiction in the dating of these 2 sites.

Another consideration concerns the shape of the calibration curve in the relevant region (Figure 1). A random sample of dates in the 10th century should produce measurements in the range $\sim 2850$ to $\sim 2750 \mathrm{BP}$, or even somewhat wider, allowing for analytical error. Dates in the 9 th century should fall between 2770 (or even higher) and 2600 BP. The Groningen Tel Rehov measurements are in fact much more limited ( 2800 to $2750 \mathrm{BP}$ ), giving the impression that the true chronological range of the Iron Age IIA phases at this site is the second half of the 10th century BCE and/or the first half of the 9 th, rather than the first half of the 10th century as claimed.

The model chosen by the Rehov investigators allows for "gaps" between "destructions" and concentrates the dates into "events." This provides a neat explanation for the lack of dates in the 2850-2800 BP range, which one would otherwise expect. The combined effects of the shape of the curve at this particular region - the "gappy" model and the fact that late Iron I is poorly represented-conspire to push the beginning of the Iron II sequence at Rehov (stratum VI) onto the little downwards wiggle at about 975-950 BCE, which is not necessarily warranted by the measurements alone.

Moreover, while the model presented by the Rehov team does posit a high probability $(68 \%)$ that the boundary between phase D3 (late Iron I) and stratum VI (lowest Iron IIA) falls in the first half of the 10th century (990-960 BCE) there is a subsidiary peak to the distribution (Bruins et al. 2005:283), which indicates a significant possibility (about 20\%) that it falls in the second half of the century (950-920 BCE). As noted above, the addition of Tel Rehov dates measured in laboratories other than Groningen enhances this peak (and in some models reverses the odds; see Sharon et al., forthcoming; cf. also Bronk Ramsey 2005:63).

This scenario perfectly exemplifies the danger of predicating the chronological scheme of an entire region on (one excavator's interpretation of) a single site or a limited set of samples analyzed by a single lab. A comprehensive study to resolve this problem was clearly in order. 


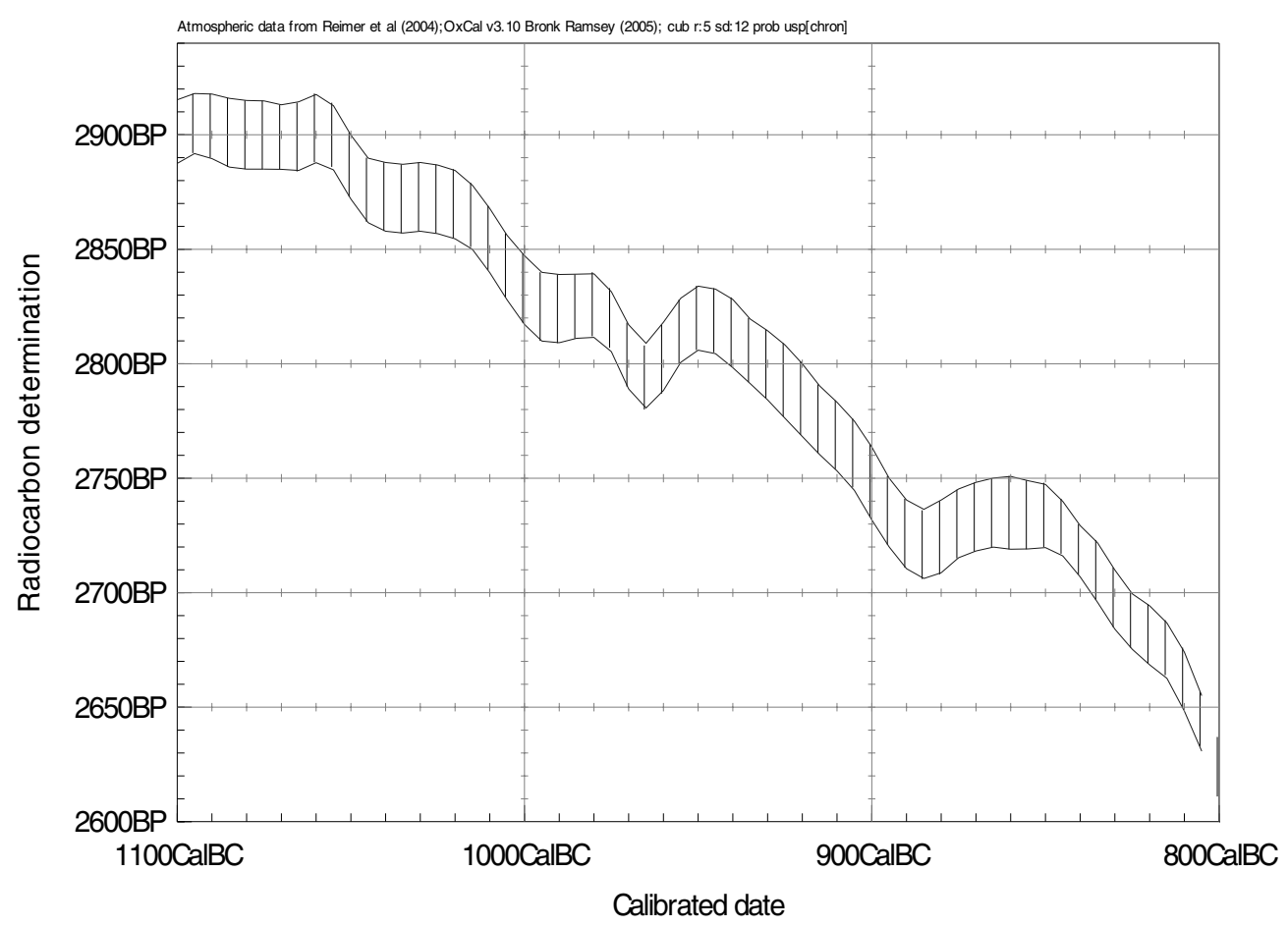

Figure 1 The IntCal04 calibration curve (Reimer et al. 2004) in the early Iron Age

\section{THE CURRENT STUDY}

To overcome these and other archaeological and analytical pitfalls in the dating process, the present project draws upon a wide range of dates from nearly all relevant sites in Israel. With generous grants from the Israel Science Foundation, we approached all the excavators of Iron Age I and IIA sites in the country and obtained (to date) 105 samples from 21 sites (Figure 2). These were replicated (see below) to produce $380{ }^{14} \mathrm{C}$ determinations, by far the largest data set bearing on the problem.

\section{Choice of Samples and Archaeological Pitfalls}

Quality control on sample collection in the field dictated that only samples originating in reliable contexts be used. Accordingly, together with the excavators, we attempted to obtain samples of either primary deposits, or otherwise uncontaminated fills, whose stratigraphic attributions are secure and with clear association to meaningful ceramic assemblages. Samples were selected from within such contexts based on size, state of preservation, and type of raw material-the preferred ones being short-lived samples (grain or olive pits). Despite all vigilance, some archaeological "noise" is inevitable; some cautionary tales are listed below.

Charcoal was only used if critical contexts or sites could not produce short-lived samples. In retrospect, charcoal indeed often produced dates that are obviously too old. One case in point: Five charcoal samples from strata XII/XI at Hazor (assays 3700-3704 in Table 7) were recovered from refuse pits with well-defined Iron Age ceramics, cut into the destruction debris of the Late Bronze Age palace. In some of these $(3703,3704)$, the date is hundreds of years too old (Middle Bronze Age, before $1600 \mathrm{BCE}) .^{1}$ This indicates either reuse of constructional wood from the defunct palace, or redepo-

${ }^{1}$ All dates referred to herein as BCE are calibrated using the 2004 calibration curve (Reimer et. al. 2004). Uncalibrated dates are referred to as BP. 


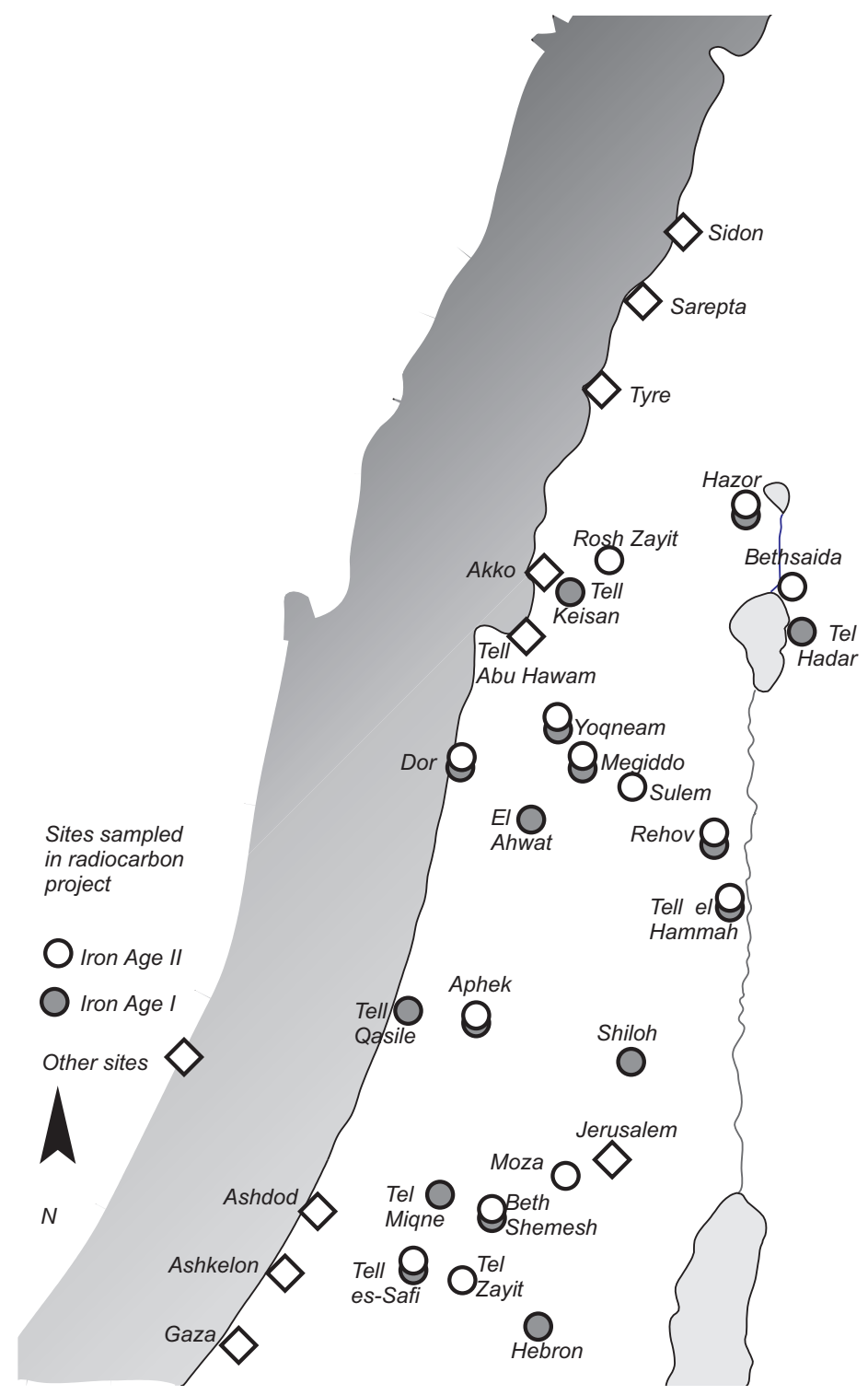

Figure 2 Map of date-producing sites

sition of charcoal from the palace destruction debris in later pits. The 3 other dates are equivocal. Our own database and other studies (Manning et al. 2001) show that dates in the range of 2950-3000 BP (about 1300-1100 BCE) may be encountered in both Late Bronze Age and early Iron Age contexts. Is this charcoal also redeposited, or can we regard these samples as bona fide?

Another type of problem was encountered at the site of Moza. Four samples (of charcoal) were taken from a "burnt layer" (L2043, samples 4583-4587 in Table 7). Above that burnt layer was a welldefined stratum of Iron II, but, on examination of the pottery from the burnt layer itself and from the fill above it, it turned out that the contexts included, in addition to some Iron Age pottery, redeposited potsherds of earlier periods (Bronze Age). Can this charcoal be used to date the Iron IIA? 
Nor is the use of only short-lived materials foolproof. A case in point is sample 4278 from Tel Zayit, which gave a date more than a thousand years too young (in the Middle Ages). The sample came from a pit, some $50 \mathrm{~cm}$ below topsoil. The pottery from the pit was entirely Iron Age. Possible explanations are an unnoticed intrusion (e.g. a rodent burrow) or that the pit was indeed dug in the Middle Ages (a period attested at this site), but no contemporary pottery was deposited in it for one reason or another. When the date is a thousand years too young (and has been verified, as in this case, by replication), the problem is clearly archaeological (an intrusion). But how many other intrusions exist where the difference is only a few decades (e.g. an undetected intrusion from one stratigraphic phase to the one immediately preceding it)?

In a few other cases, excavators changed their minds about the attribution of contexts that were sampled. In one case (e.g. sample 4288 from Tel Miqne), ${ }^{14} \mathrm{C}$ analysis indicated a much later date than the relative archaeological context supplied by the excavators. In a re-examination of the context, it was recognized that the locus was contaminated by intrusive material. In another case from the same site (sample 4282), the excavators changed the phase designation without any indication from the ${ }^{14} \mathrm{C}$ dates that something was amiss (note the different stratigraphic designation in Table 7 vs. Boaretto et al. 2005: Table 1).

As a last case in point: Sample 4281 is from a granary under the stratum V gate at Bethsaida, and hence is attributed by the excavator to stratum VI. The context itself did not yield any indicative pottery. The excavator dates stratum VI to Iron IIA, but this dating is based on an assemblage found in another excavation area, some $30 \mathrm{~m}$ away. The quality of the organics (many liters of burnt grain) however, was such that we felt we had to sample it, pending substantiation of the claim that it dates to the Iron Age IIA.

Such cases serve as reminders that the link between the ${ }^{14} \mathrm{C}$ sample and the cultural episode one wants to date is never straightforward, and as warnings that in any database, other, less evident, archaeological errors may exist. The opposing danger is that in not reporting on suspect samples, one may unwittingly be biasing the database in favor of one's preconceived notions (naturally a date in keeping with one's belief would not be suspect). We adopted a strategy of transparency: we tried to discriminate in our choice of samples, but once a sample has been chosen and dated it is not removed from the database.

\section{${ }^{14} \mathrm{C}$ ANALYSIS AND QUALITY CONTROL IN THE LABORATORIES}

${ }^{14} \mathrm{C}$ analysis was performed mainly in the Rehovot and Tucson laboratories, using both LSC and AMS techniques, and several samples were also dated at Groningen, using AMS. Quality control in the laboratories consisted of the following procedures: AMS was chosen as the primary method for this study, as size constraints prevent decay counting to be replicated except for exceptionally large samples. In 14 of these larger samples, the bulk of the sample was turned to benzene for liquid scintillation counting (usually only a single vial could be extracted, denoted in Table 7 as "Rehovot LSC"), but some was set aside for graphitization for AMS. AMS was always performed on multiple targets (except for a few cases that were too small or in which one or more of the targets was a dud). Specimens of all the samples labeled "Rehovot AMS" were pretreated as described in Alon et al. (2002; Yizhaq et al. 2005), graphitized in Rehovot, and then run in Tucson. Twenty-two samples were split between the 2 laboratories before cleaning (Boaretto et al. 2005). In these cases, charcoal samples were mechanically cleaned and homogenized prior to splitting, while olive seeds were sent raw and complete. One portion was then pretreated at Rehovot (as described above) while the other portion (measurements listed in Table 7 as "Tucson AMS") was both pretreated and measured at Tucson. 
Intercomparison was also conducted with the Groningen Center for Isotope Research, on 8 samples. These include 5 samples split between Rehovot and Groningen (3778, 3931, 4410, 4531, 4540), according to the same protocol as above (see also Boaretto et al. 2005). Sample 3778 was also part of the Rehovot-Tucson intercomparison exercise and also dated by LSC. Three additional samples (3805, 3807, 3809) were from contexts at Tel Rehov previously examined at Groningen and reported in Bruins et al. (2003). In these 3 cases, the samples we dated were from the same contexts but are not necessarily identical. All 3 were dated at Groningen by GPC and one also by AMS. One of them (3807) was also dated (twice) by LSC in Rehovot, and another (3809) by AMS in Tucson.

In cases that showed anomalies, a second run of AMS was performed. On average, each sample was measured 3 times, but some were measured as many as 9 times. In a few cases, where anomalies were linked to specific experimental protocols or laboratory procedures (see details in Boaretto et al. 2005; Sharon et al. 2005), the entire set of measurements performed under such conditions was excluded-whether or not the results were divergent. In no case, however, was a measurement summarily dismissed simply because "it does not fit." A case in point: in sample 3943, the third cathode produced an age more than 3 standard deviations away from the average. The reason for this may have been graphite improperly pressed into the cathode, as has been the case in some other anomalous measurements (Boaretto et al. 2005; Sharon et al. 2005). However, in this case the cathode was not available for inspection and therefore this measurement was not removed from the list.

\section{OUTLIER ANALYSIS}

The extensive replication procedure also allows for a rigorous treatment of outliers. The different options we considered for identifying and treating aberrant results are discussed in detail in Boaretto et al. (2005:43) and Sharon et al. (2005:71-78). In this paper, we only present briefly the results as they pertain to the database presented here. First, we calculated the weighted average of each replicated set and computed the standardized residual (Scott 2003:383; Sharon et al. 2005:72) for each measurement. An overall $\chi^{2}$ statistic was defined as the sum-of-square-residuals over the entire database, and the highest absolute residuals were excluded from the data set in a stepwise fashion, until the overall significance $(\alpha)$ of the overall $\chi^{2}$ dropped below $5 \%$. Out of 380 measurements, this state $(\alpha=10 \%)$ was reached after the removal of the 4 highest residuals ( $1 \%$ of the total).

We give here 1 example to illustrate the process and its potential problems. Sample 3932 (legumes from the late Iron I destruction of stratum X at Tell Qasile) produced the following results (see Table 1).

Of the 6 measurements, one is very low (3932.6) and one is very high (3932aa), and indeed the $\chi^{2}$ (for this assay only) is rather high, giving less that $1 \%$ probability of this spread being entirely random. Removing 3932.6 would give a weighted date of $2779 \pm 20 \mathrm{BP}$ and a $\chi^{2}$ value of $8.34(\alpha=$ $8 \%$ ), while removing 3932aa would produce a weighted average of $2724 \pm 20 \mathrm{BP}$ and a $\chi^{2}$ of 7.07 $(\alpha=13 \%)$. In each case, the truncated data set would have passed the $\chi^{2}$ test. Note, however, that the standardized residual of 3932aa is the highest in the set (in absolute value) and that, indeed, removing 3932aa results in a better overall fit for the rest of the measurements. Thus, our procedure would prefer to remove this measurement. As assay 3932 is indeed one of the very low dates in Iron I, the 50-yr difference between the 2 averages may actually be significant for the overall result. However, this is indeed the extreme case. In most other assays, the outlying measurement was unambiguous.

This, however, is not the end of the story. While having 2 measurements out of 6 vary by more than 2 standardized residuals from the norm is indeed highly unlikely, in a study involving over 350 mea- 
Table 1 Six replications of sample 3932. Potential outliers are in bold.

\begin{tabular}{|c|c|c|c|c|c|c|c|c|c|c|c|c|}
\hline $\begin{array}{l}\text { Site \& } \\
\text { stratum }\end{array}$ & Type & Sample & Analysis & $\begin{array}{l}\text { Age } \\
\text { (BP) }\end{array}$ & $\sigma$ & $\begin{array}{l}\text { W. } \\
\text { AVG }\end{array}$ & $\begin{array}{l}\mathrm{C} \\
\sigma\end{array}$ & Residual & $\chi^{2}$ & df & $\sigma$ & $\begin{array}{l}\text { Relative } \\
\text { date }\end{array}$ \\
\hline \multirow{6}{*}{$\begin{array}{l}\text { Qasile } \\
\text { X } \\
\text { L168 }\end{array}$} & \multirow[t]{6}{*}{ Lathyrus } & 3932.3 & $\begin{array}{l}\text { Rehovot } \\
\text { AMS }\end{array}$ & 2745 & 50 & \multirow[t]{6}{*}{2752} & \multirow[t]{6}{*}{18} & -0.1437 & \multirow[t]{6}{*}{16.6} & \multirow[t]{6}{*}{5} & \multirow[t]{6}{*}{$1 \%$} & \multirow[t]{6}{*}{ Iron I (1) } \\
\hline & & 3932.4 & $\begin{array}{l}\text { Rehovot } \\
\text { AMS }\end{array}$ & 2765 & 75 & & & 0.17084 & & & & \\
\hline & & 3932.5 & $\begin{array}{l}\text { Rehovot } \\
\text { AMS }\end{array}$ & 2685 & 50 & & & -1.3437 & & & & \\
\hline & & 3932.6 & $\begin{array}{l}\text { Rehovot } \\
\text { AMS }\end{array}$ & 2650 & 40 & & & -2.5547 & & & & \\
\hline & & $3932 a$ & $\begin{array}{l}\text { Tucson } \\
\text { AMS }\end{array}$ & 2780 & 35 & & & 0.79467 & & & & \\
\hline & & 3932aa & $\begin{array}{l}\text { Tucson } \\
\text { AMS }\end{array}$ & 2862 & 40 & & & 2.74533 & & & & \\
\hline
\end{tabular}

surements we should expect to find several deviations of such magnitude. Indeed, the stepwise removal of outliers has reached an acceptable level of agreement before any of the sample 3932 measurements had been removed. In this case, the prudent course was to leave both measurements in.

After removal of outliers in this fashion, weighted averages were recalculated per sample, and the measurement errors combined to produce reduced error estimates. These are referred to below as "combined dates."

Concurrently, we used another procedure. Along with the weighted average and combined error estimates we also calculated - before removal of any suspected outliers-the (unweighted) average for each sample and the standard deviation between the measurements. Of the 2 pairs of central moments and error estimates, we then used the one with the larger deviation (Bevington and Robinson 1992). We refer to this method below as "cautious error estimation." There is some indication that conventional error-estimation techniques may tend to underestimate the actual deviation that would be obtained under extended replication (Scott et al. 2003:213-218, 252-260, and Figures 7.1-7.7). This method, on the contrary, almost certainly overestimates them. In the case of assay 3932 (see Table 1), the "cautious" estimate of the date would be $2748 \pm 68$ BP.

A third way of treating analytic outliers (or, rather, of not treating them) is to simply not combine the measurements, and model the archaeological phases with the individual measurements as point estimates, rather than with a single estimate per sample. This would essentially move the onus of identifying outliers to the next stage of analysis. The logic behind this would be: "If we don't know if measurement $\mathrm{X}$ or $\mathrm{Y}$ is [more] correct, let's put them both in the model and see how they fit with other measurements of the same archaeological horizon." Such a procedure is open to objection on 2 grounds. First, it tends to give extra weight to samples that were replicated many times. Note, however, the fact that combining measurements always reduces the error estimate (regardless of how similar or dissimilar the actual measurements are!) and causes the exact same effect. Secondly, several replicated measurements of the same sample cannot be regarded as statistically independent. The question of dependence is complex, and is most often ignored in archaeological studies. Can several (different) samples from the same locus or layer in a site be considered independent? Often, we do not even know if they represent the same event or not. An even more complex question, in a study like ours that considers different sites, is the effect of a regional sequence that is out of synch (even slightly so) with another one. In such a case, we might be consistently sampling something 
slightly earlier, or slightly later, in one site or region than in another. We may, however, at least assert that given that the horizons being sampled are fairly short (relative to the analytical error), fairly (though not perfectly) well-defined, and fairly densely sampled, the effect of these complex dependencies and partial dependencies would be quite small. At any rate, we regard "uncombined" models as suspect, though they are included here for the purpose of robustness analysis.

\section{RELATIVE PERIODIZATION OF THE IRON AGE I-IIA IN ISRAEL}

The date-producing contexts were seriated by intersite stratigraphical order and intrasite ceramic considerations and clustered into 8 chronological horizons. The basis for this subdivision was extensively discussed in Gilboa and Sharon (2003) and Sharon et al. (2005). We offer here some justification of the scheme as a whole, without going into minutiae of specific pottery types or why a particular stratum was classified to horizon $\mathrm{X}$ and not $\mathrm{X}+1$.

A typochronological framework was first devised for the Phoenician coast (including Dor), which is the region that offers the most detailed early Iron Age stratigraphic/ceramic sequences in the southern Levant. It also allows a high-resolution tracing of typological developments of vessels/ wares that are also frequently found outside this region and thus can be used to overcome problems of ceramic regionalism. The most important among them are painted Cypriot, Phoenician, and Philistine ceramics. Though we devised a new chronological terminology for Phoenicia (Gilboa and Sharon 2003:10-11), the basic typological criteria with which we attempted the subdivision of the Iron Age I are well known and widely accepted in the archaeological community.

The painted pottery typical of Philistia undergoes a sequence of stylistic development: The initial finely-levigated and highly-fired Monochrome ware with Aegean forms and freehand designs (Dothan and Zukerman 2004) is replaced by "Philistine Bichrome" (Dothan 1982: chapter 3), which gradually "degenerates" (e.g. Dothan 1982:191-198); "Canaanizes" (Mazar 1985:119-120); "acculturates" (Stone 1995:19); "Creolizes" (Maeir 2004). In other words, it loses its distinctively Aegean form and decoration, is often red-slipped, and the painted decoration often becomes simple and schematic. Finally, it transforms into the "Late Philistine Decorated Ware" typical of the Iron Age IIA (Ben-Shlomo et al. 2004), in which the geometric decoration (black and white on red slip) is instrumentally applied.

In Phoenicia, meanwhile, "late Canaanite ware" or "Phoenician monochrome" (Gilboa 1999a) transforms into the famed "Phoenician Bichrome," which is typical of the later part of Iron I and goes on (with several distinct changes) into Iron II (Anderson 1990; Gilboa 1999a), when it begins to appear together with "Phoenician Red Slip."

These 2 trajectories are corroborated by the evolution of Cypriot ceramics: The end of the "real" Late Bronze Age (LB) in the Levant parallels the Late Cypriot (LC) II. Typical LC II imports, such as White Slip and Base Ring wares, which are found in abundance in all LB sites, cease towards the very end of the Levantine Bronze Age. Then comes LC IIIA, which by Cypriot imports in the Levant, and vice versa, correlates with the horizon here termed the LB|IR transition (for which see below) (e.g. D'Agata et al. 2005). LC IIIB imports have not been found in Israel, but the following Cypro-Geometric (CG) IA is found in the same contexts with the earliest Phoenician Bichrome both in Cyprus and in Phoenicia (Iacovou 1999; Gilboa 1999b; Gilboa and Sharon 2003). This evolves, via the CG IB-CG II stage (e.g. Coldstream 1999; Sharon et al. 2005:68-70 and references) to CG III, mostly represented by Cypriot Black on Red ware. The latter is evident in almost all Iron IIA assemblages in the Levant (Schreiber 2003: mainly chapters 3 and 4; Gilboa and Sharon 2003:62$63,66-67)$. 
Table 2 Samples seriated into 8 chronological horizons. LB = Late Bronze Age; IR = Iron Age. The italicized numbers are the sample numbers. Asterisks denote charcoal samples (the rest are shortlived samples). The individual measurements for each sample are listed in Table 7.

\begin{tabular}{|c|c|c|c|c|c|c|c|}
\hline LB & LB|IR & & IR I & IR I|II & \multicolumn{2}{|c|}{ IR IIA } & IR IIB \\
\hline \multirow[t]{3}{*}{$\begin{array}{l}\text { Aphek } \\
\text { X12: } \\
4510 \\
\text { Tel } \\
\text { Zayit: } \\
4274\end{array}$} & \multirow[t]{3}{*}{$\begin{array}{l}\text { Megiddo } \\
\text { K/6 } \\
\text { [=VIIA?]: } \\
\text { 4499, } \\
\text { 4500, 4501 } \\
\text { Miqne } \\
\text { VIIb: } \\
\text { 4286 } \\
\text { Keisan 13: } \\
\text { 3804* }\end{array}$} & \multicolumn{2}{|c|}{$\begin{array}{l}\text { Ahwat: } 4270,4271,4272,4273 \\
\text { Hazor XII/XI: } 3700^{*}, 3701 * \text {, } \\
3702,3703 *, 3704^{*} \\
\text { Shiloh V: } 3927,3928,3929 \\
\text { Hebron VII: } 4147 *, 4148^{*} \\
\text { Rehov D4: } 3809\end{array}$} & \multirow[t]{3}{*}{$\begin{array}{l}\text { Aphek } \\
\text { X8: } 4511\end{array}$} & \multicolumn{2}{|c|}{$\begin{array}{l}\text { Rosh Zayit IIA: } 3797, \\
3798,3799 \\
\text { Rehov D/2: } 3807 \\
\text { Rehov E/1b: } 3808 \\
\text { Bethsaida 6: } 4281 \\
\text { Sulem: } 3989^{*}, 3990^{*} \text {, } \\
3991^{*} \\
\text { Moza: } 4583^{*}, 4584^{*}, \\
\text { 4586*, 4587* }\end{array}$} & \multirow[t]{3}{*}{$\begin{array}{l}\text { Beth } \\
\text { Shemesh } \\
\text { 3: } 3937, \\
\text { 3938 } \\
\text { Tel Zayit } \\
\text { I: } 4275 \text {, } \\
4278 \\
4279^{*} \\
4280^{*}\end{array}$} \\
\hline & & IR I (e) & IR I (1) & & IR IIA & IR II A|B & \\
\hline & & $\begin{array}{l}\text { Beth } \\
\text { Shemesh } \\
\text { 6: } 3934 \\
\text { Beth } \\
\text { Shemesh } \\
\text { 5: } 3935 \text {, } \\
3936 \\
\text { Dor D2/ } \\
\text { 13: } 4528 \\
\text { Dor D2/ } \\
\text { 12: } 4522 \text {, } \\
4525 \\
\text { Miqne } \\
\text { VIb: } 4283 \\
\text { Miqne } \\
\text { Vb: } 4282 \text {, } \\
4284\end{array}$ & $\begin{array}{l}\text { Megiddo K-4 } \\
\text { =VIA: 3939, } \\
\text { 3940, 3942, 3943, } \\
\text { 3944, 3945, 3946 } \\
\text { Qasile X: 3853, } \\
\text { 3930, 3931, 3932, } \\
\text { 3933 } \\
\text { Dor D2/10-9: } \\
\text { 4531, 4532 } \\
\text { Tel Hadar IV: } \\
\text { 3795, 4291 } \\
\text { Rehov D3: 3805, } \\
\text { 3806 } \\
\text { Hammah } \\
\text { [lower]: 4416*, } \\
\text { 4417 } \\
\text { Keisan 9b: } 3801 * \\
\text { Keisan 9a-b: } \\
\text { 3802* } \\
\text { Keisan 9a: } 3796, \\
\text { 3803* } \\
\text { Yoqne‘am XVII: } \\
\text { 3777, 3778, 3779* }\end{array}$ & & $\begin{array}{l}\text { Hazor X: } \\
3782^{*}, \\
3783^{*}, \\
3784,3786 \\
\text { Megiddo } \\
\text { H5 [=IVB- } \\
\text { VA]: } 3949 \\
\text { Yoqne'am } \\
\text { XIV: } 3780^{6} \\
\text { Hammah } \\
\text { [mid]: } \\
4411,4412 \text {, } \\
4413,4414, \\
4415,4418 \text {, } \\
4419,4420 \text {, } \\
4423,4424 \text {, } \\
4425 \\
\text { Dor D2/8b: } \\
4556\end{array}$ & $\begin{array}{l}\text { Safi IV: } \\
4409 \text {, } \\
4410 \\
\text { Hammah } \\
\text { [upper]: } \\
4422 \\
\text { Hazor IX: } \\
3785^{*}\end{array}$ & \\
\hline \multirow[t]{2}{*}{ Total: 2} & \multirow[t]{2}{*}{ Total: 5} & Total: 9 & Total: 27 & \multirow[t]{2}{*}{ Total: 4} & Total: 18 & Total: 4 & \multirow[t]{2}{*}{ Total: 6} \\
\hline & & & al: 51 & & \multicolumn{2}{|c|}{ Total: 35} & \\
\hline
\end{tabular}

Grand total (samples): 103

In order to avoid the debate as to whether sites with finds relating to the Egyptian 20th Dynasty should be relegated to the end of the Late Bronze Age or to "Iron Age IA" (Ussishkin 1985 vs. Mazar 1990:290), and whether they pre-date or coincide with the first appearance of Philistine wares (the latter possibility, however, is our preference; see summary of the different views in Finkelstein 2000:162-165), we grouped these together into a category we label, for convenience, "LB|IR transition." "Terminal Late Bronze Age" assemblages that no longer have Cypriot/Mycenaean imports, assemblages with 20th Dynasty Egyptian artifacts, or "Philistine Monochrome" and/ or LC IIIA imports were all placed under this label.

Assemblages with "Philistine Bichrome" and/or pre-dating the appearance of "Phoenician Bichrome" were classified as "Iron Age I (early)," while those exhibiting the late "degenerate" phase of Philistine decoration and/or Phoenician monochrome, early "Phoenician Bichrome," and/ or having CG IA imports were classified as "Iron Age I (late)." 
The transitional Iron I|II horizon is that postdating the late Iron I levels and preceding the "classical" Iron IIA occupations, and is coeval with Cypriot CG IB-II. The chronological significance of this horizon has been recognized lately by scholars dealing with northern sites in Israel (with some variations, e.g. calling it "early Iron IIA"). (For an explicit discussion of this horizon, see Sharon et al. 2005:67-70; Zarzecki-Peleg 2005:368, 376; cf. also Mazar 2004:68.) This horizon does not parallel "late Iron I" at Tel Rehov, as suggested in Mazar (2005: n. 6). If anything, it should correspond to stratum VI, in as much as this stratum precedes the beginning of CG III wares at Rehov.

There is a general agreement on occupational strata assigned to Iron IIA (see Mazar 2005: Table 24; for the pottery, Ben-Tor and Zarzecki-Peleg, forthcoming), but divisions within this period are difficult (that, in itself, might indicate that it is fairly short). In our terminology, Iron IIA strata in the north are the "classic" Iron IIA strata (considered Solomonic by the High Chronology). All of these strata contain Cypro-Geometric III pottery and some have Euboean Sub-Proto-Geometric imports too. Correlation with Iron IIA sites in the south is more complex. Regarding Judah, Herzog and Singer-Avitz (2004) suggested lately that the horizon hitherto regarded there as late Iron I be termed "early Iron IIA." This horizon probably corresponds to our transitional horizon, and their "later Iron IIA" probably parallels our Iron IIA. Because we do not possess samples from this region, we did not tackle this issue further. Occupations stratigraphically placed late in the Iron IIA sequences in their respective sites were termed Iron IIA|B (cf. Zarzecki-Peleg 2005:376). Some contexts were defined as "general Iron IIA," with no attempt at subdivision.

In as much as the scheme proposed herein has any novelty, it is in being explicitly seriative-every 2 temporal categories have an "intermediate" between them. We use the symbol | to denote this. This reflects our conviction that change in artifactual assemblages is gradual, quantitative, and durative, i.e. "types" do not appear or disappear overnight but rather slowly and constantly gain or lose popularity as well as undergo gradual morphological change. This, of course, is hardly revolutionary, and yet the very fact that the periodization models we use force us to pigeonhole assemblages in "periods" encourages a punctuative view of cultural change-in which one envisions instantaneous upheaval between periods vs. no change at all within the period itself (e.g. Mazar 2005:21).

The other feature that characterizes the proposed scheme is that it allows for the inclusion of assemblages that cannot be precisely placed, other than in a very general category ("Iron I" or "Iron IIA"). Some assemblages defy very precise seriation, either because of the nature of the assemblage, the nature of the site, the nature of the excavation, or the nature of the publication.

An important case in point: the "Israelite Settlement" sites in the hill country are poorly seriated. These are often single-occupation and/or very shallowly stratified sites, so building a typological sequence based on internal stratification is impossible. They are also usually very poor sites, so correlating them with richer (and more richly stratified) sites in the lowlands on the basis of imports is difficult. Very few of them are excavated, even fewer are adequately published, and many of these reports are rather old. The net result is that we are unable to offer a very precise seriation for a critical region for one of the central issues under debate (sites in the database in this category are Shiloh, Hebron, and El-Ahwat).

While the scheme as presented is indeed fairly complex, a complex scheme can always be simplified. In the following, we shall show several simplified models that were derived from this scheme. Indeed, the extent to which different (legitimate) models of the same data show similar overall results is a strong test for the robustness of the data set. 
Having said all that, there still is, of course, an almost endless amount of tinkering that can be done with the models. Certainly, some archaeologists might feel that some assemblage that we are cautious about might be put in a more precisely seriated category, or vice versa. Some may suggest entirely different criteria to break the sequence of the same assemblages in different ways. Far be it from us to claim that the "Philistine potters' guild" decided to "degenerate" on the same day that the "Phoenicians" "invented" the Bichrome style. We only assert that such trajectories are useful tools for grouping together more-or-less contemporaneous assemblages. Indeed, this data set is so rich that it will probably serve as the basis for chronological modeling for years to come. Our purpose in the following is to present the data, together with what we think are the most reasonable ways to model it.

\section{MODELING}

The scheme introduced above allows for the main subject of interest - the transition between the Iron I and II - to be calculated using different Bayesian models, operating at different levels of resolution and employing different parts of the data. Each model was run both with all the relevant assays-short- and long-lived and on the short-lived assays only.

The simplest (and crudest) model is to lump together all the dates from Iron I contexts vs. all the dates for Iron II contexts (Table 3 ) and to model the likelihood of a boundary point in between these 2 groups. Below, this is referred to as "the coarse model." In OxCal (Bronk Ramsey 2001) notation, this simple model is presented in Figure 3.

This model does not include Late Bronze Age and transitional LB|IR contexts. It also does not include the contexts labeled "transitional Iron I|II." This might introduce a problem, as we a priori know that there is a gap between the 2 categories. One can try 2 additional models wherein these dates are either regarded as "late Iron I" or "early Iron II," and lumped with the appropriate group; but we have not done so in this instance. Samples excluded at the outset were the Tel Zayit Middle Ages one and the Hazor Middle Bronze Age ones. Though we explained above our reluctance to exclude samples from the data set, such huge misfits simply prevent the convergence of the algorithm; and the fact that these dates are out of the bounds of discussion is obvious. Other extremely high (and extremely low) dates (e.g. assay 3625 from Dor D2/12, which at $3029 \pm 28$ BP is definitely earlier than $1200 \mathrm{BCE}$ ) were initially left in (see below for treatment of misfits).

Another simple model that can be drawn from the data set will be referred to as the "focused model" (Figure 4). It uses only the most relevant contexts for the question at hand, i.e only those of the late Iron I, transitional Iron I|II, and early Iron IIA horizons. Of interest to us in this case are 2 boundaries: the one between late Iron I and the "transitional" horizon, and the one between the "transitional" horizon and the "classical" Iron IIA. The advantage of this model is that it disregards contexts that are far removed from the transition we are after, and imprecisely seriated ones, but it uses only 49 of the 109 assays. If we limit ourselves to short-lived samples, only 40 assays are used (Table 4).

Finally, the third model is the one representing the entire scheme utilizing as much information as possible. We call this the "composite model" (Table 5 and Figure 5). Within the basic sequence of 6 typological horizons, the Iron I and Iron IIA were further divided (by an internal sequence) into early and late sub-phases. This model allows us to use dates from "unordered" Iron I and Iron IIA contexts, as well as ones for which a finer attribution can be offered. 
Table 3 The coarse model. Contexts and sample numbers (in italics) are listed, charcoal samples with asterisks. The shaded cells are ones not used in this model. Crossed-out samples are misfits excluded during the model run (see below). Totals in parentheses exclude charcoal samples.

\begin{tabular}{|c|c|c|c|c|c|c|c|}
\hline LB & $\mathrm{LB} \mid \mathrm{IR}$ & & R I & IR I|II & IR & & IR IIB \\
\hline \multirow[t]{3}{*}{$\begin{array}{l}\text { Aphek } \\
\text { X12: } \\
4510 \\
\text { Tel } \\
\text { Zayit: } \\
4274\end{array}$} & \multirow[t]{3}{*}{$\begin{array}{l}\text { Megiddo } \\
\text { K/6 } \\
\text { [=VIIA?]: } \\
4499 \text {, } \\
4500 \text {, } \\
4501 \\
\text { TelMiqne } \\
\text { VIIb: } \\
4286 \\
\text { Keisan } \\
\text { 13: } 3804 *\end{array}$} & \multicolumn{2}{|c|}{$\begin{array}{l}\text { El Ahwat: 4270, 4271, 4272, } \\
4273 \\
\text { Hazor XII/XI: } \\
\text { 3700*, 3701*, 3702, 3703*,-- } \\
\text { 3704* } \\
\text { Shiloh V: 3927, 3928, 3929 } \\
\text { Tel Hevron VII: 4147*, 4148* } \\
\text { Tel Rehov D4: } 3809\end{array}$} & \multirow[t]{3}{*}{$\begin{array}{l}\text { Dor } \\
\text { D2/8c: } \\
4540 \\
4541 \\
4542 \\
\text { Aphek } \\
\text { X8: } \\
4511\end{array}$} & \multicolumn{2}{|c|}{$\begin{array}{l}\text { Rosh Zayit IIA: } 3797 \text {, } \\
\text { 3798, 3799 } \\
\text { Rehov D2: } 3807 \\
\text { Rehov E1b: } 3808 \\
\text { Bethsaida 6: } 4281 \\
\text { Sulem: } 3989 *, 3999^{*} \text {, } \\
\text { 3991* } \\
\text { Moza: 4583*, 4584*, } \\
\text { 4586*, 4587* }\end{array}$} & \multirow[t]{3}{*}{$\begin{array}{l}\text { Beth } \\
\text { Shemesh } \\
\text { 3: } 3937, \\
3938 \\
\text { Tel } \\
\text { Zayit I: } \\
4275, \\
4278, \\
4279^{*}, \\
4280^{*}\end{array}$} \\
\hline & & IR I(e) & IR I(l) & & IR IIA & IR IIA|B & \\
\hline & & $\begin{array}{l}\text { Beth } \\
\text { Shemesh 6: } \\
3934 \\
\text { Beth } \\
\text { Shemesh 5: } \\
\text { 3935, 3936 } \\
\text { Dor D2/13: } \\
\text { 4528 } \\
\text { Dor D2/12: } \\
\text { 4522, 4525, } \\
\text { Miqne VIb } \\
4283 \\
\text { Miqne Vb } \\
4284\end{array}$ & $\begin{array}{l}\text { Megiddo K/4 } \\
\text { =VIA: 3939, } \\
\text { 3940, 3942, } \\
\text { 3943, 3944, } \\
\text { 3945, 3946 } \\
\text { Qasile X: 3853, } \\
\text { 3930, 3931, } \\
\text { 3932, 3933 } \\
\text { Dor D2/9-10: } \\
\text { 4531, 4532 } \\
\text { Tel Hadar IV: } \\
\text { 3795, 4291 } \\
\text { Rehov D3: } \\
\text { 3805, 3806 } \\
\text { Hammah } \\
\text { [lower]: 4416*, } \\
4417 \\
\text { Keisan 9b: } \\
\text { 3801* } \\
\text { Keisan 9a-b: } \\
\text { 3802* } \\
\text { Keisan 9a: } \\
3796,3803 * \\
\text { YoqneamXVII: } \\
\text { 3777, 3778, } \\
3779 *\end{array}$ & & $\begin{array}{l}\text { Hazor X: } \\
3782 *, \\
3783 *, 3784, \\
3786 \\
\text { Megiddo H/ } \\
5 \text { [=IVB- } \\
\text { VA]: } 3949 \\
\text { Yoqne'am } \\
\text { XIV: } 3780 * \\
\text { Hammah } \\
\text { [mid]: 4411, } \\
4412,4413 \text {, } \\
4414,4415 \text {, } \\
4418,4419 \text {, } \\
4420,4423 \text {, } \\
4424,4425 \\
\text { Dor D2/8b: } \\
4556\end{array}$ & $\begin{array}{l}\text { Safi IV: } \\
4409 \text {, } \\
4410 \\
\text { Hammah } \\
\text { [upper]: } \\
4422 \\
\text { Hazor } \\
\text { IX: } \\
3785^{*}\end{array}$ & \\
\hline
\end{tabular}

Total: $49(41)$

Total: $41(28)$

Total samples for model: $90(69)$

Sequence (Agglomerated Dates IR I vs. IR II)

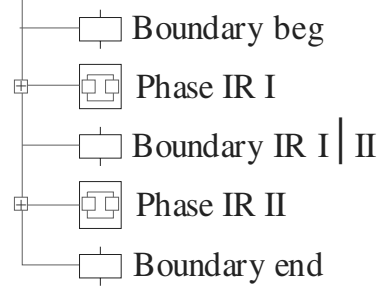

Figure 3 The coarse model: all Iron I dates vs. all Iron II dates 
Table 4 The focused model. Contexts and sample numbers (in italics) are listed, charcoal samples with asterisks. The shaded cells are ones not used in this model. Crossed-out samples are misfits excluded during the model run (see below). Totals in parentheses exclude charcoal samples.

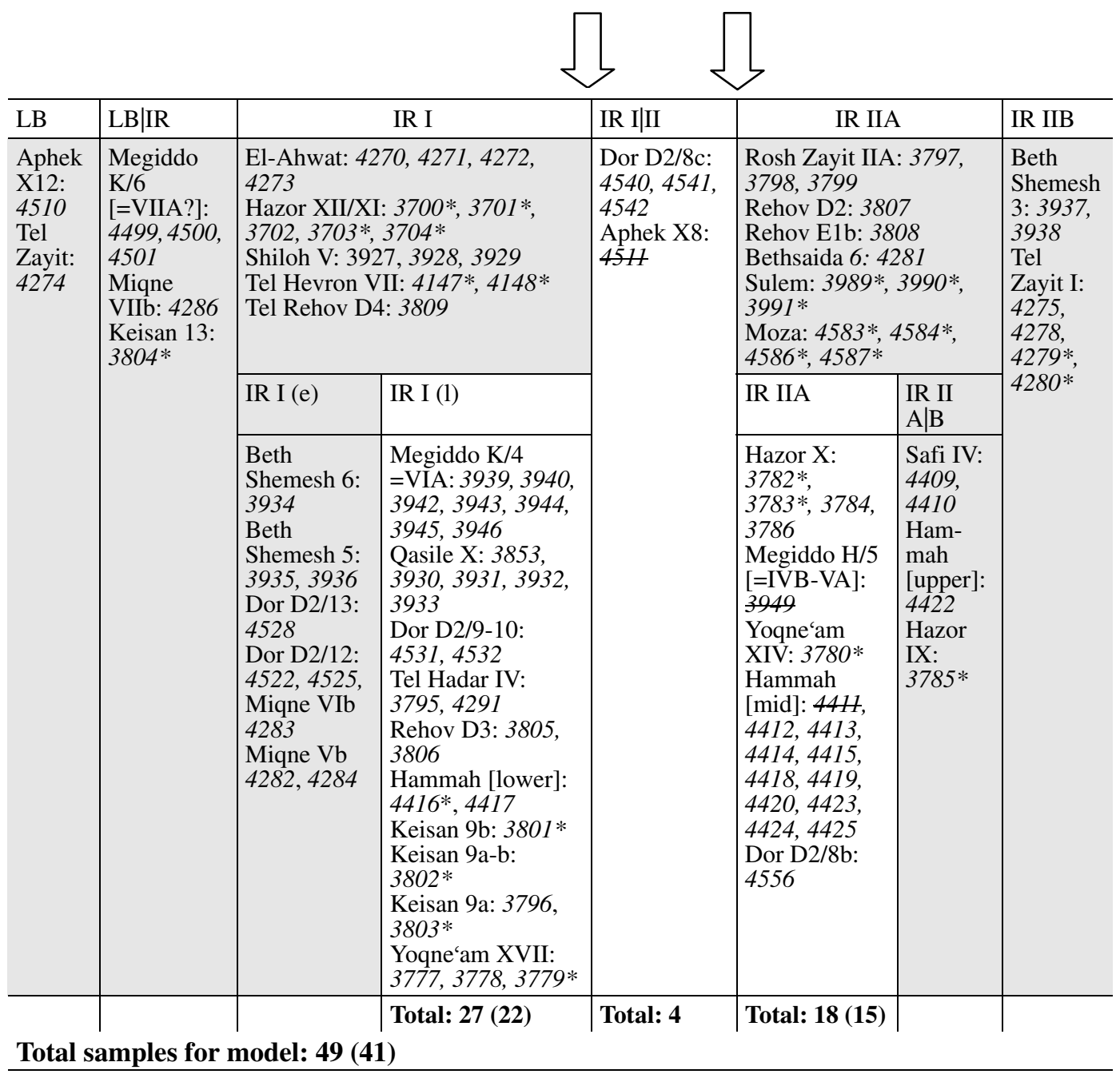

Sequence (Focused Model)

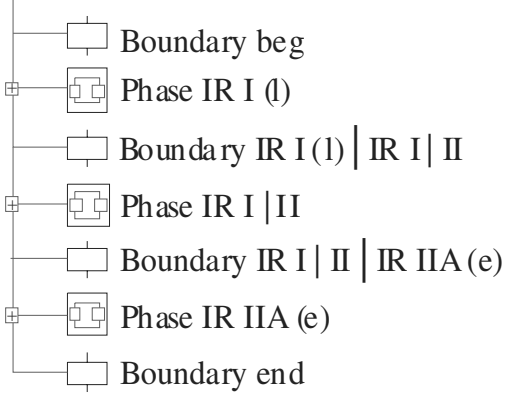

Figure 4 The focused model in OxCal notation 
Table 5 The composite model. Contexts and sample numbers (in italics) are listed, charcoal samples with asterisks. Crossed-out samples are misfits excluded during the model run (see below). Totals in parentheses exclude charcoal samples.

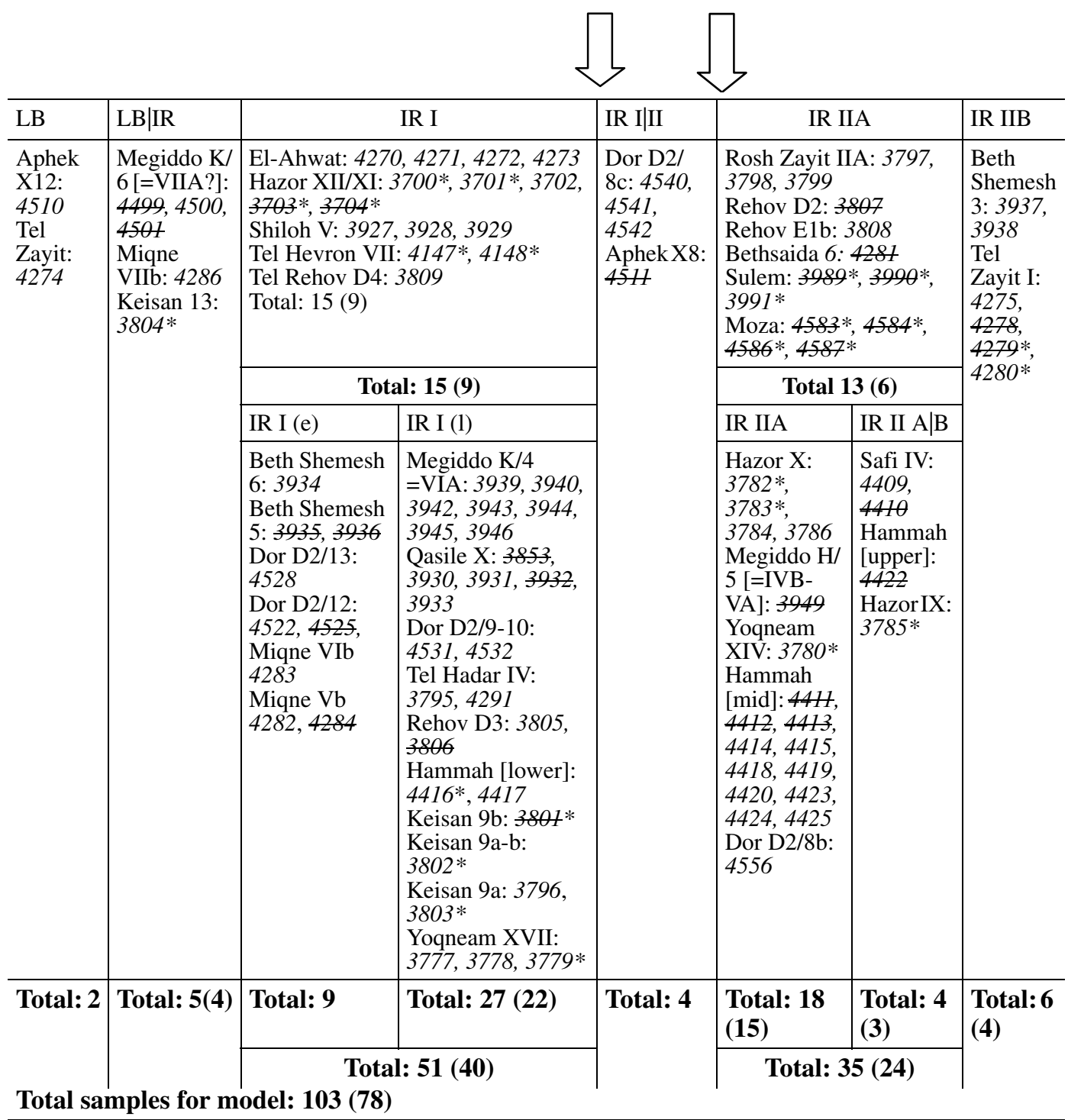

The only samples not included in this model are 4288 from Tel Miqne (from a disturbed context) and 3987 from Beth Shemesh (unclear if late Iron I, Iron I|II, or Iron IIA). To avoid "infinite improbability" and non-converging simulations, we had to remove the worst misfits at the outset. This included, in addition to the 2 Hazor Middle Bronze Age dates and the Tel Zayit Middle Ages one, also 4501 (super-low Megiddo VII) and the 2 highest Moza dates (from the locus in which Bronze Age fragments were found; both these dates are entirely in the 12th-11th century-much too high for Iron II, on any chronology). 


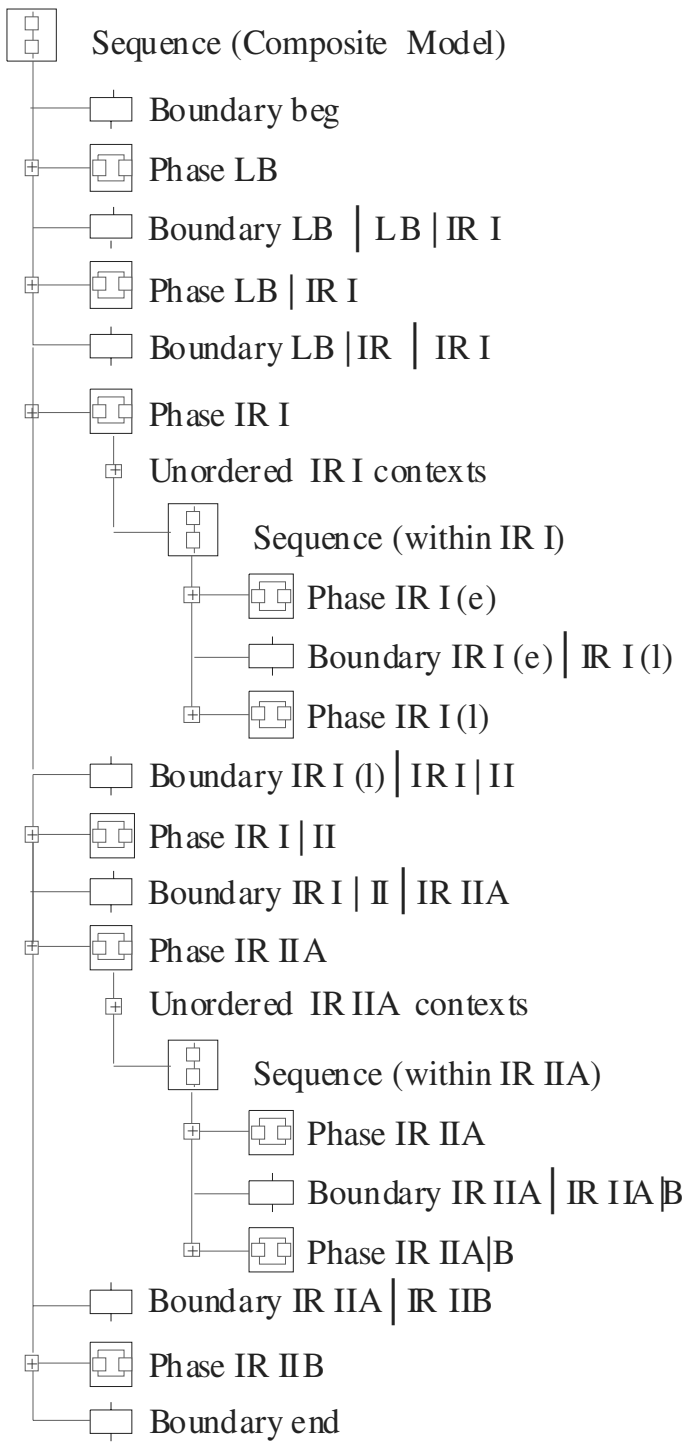

Figure 5 The composite model in OxCal notation

The composite model calculates a whole sequence of boundary distributions, but again, the ones of interest for the purpose of this study are between the (late) Iron I and the "transitional" Iron I|II horizon, and between the "transition" and the "classical" Iron IIA.

\section{HANDLING MISFITS}

We have already stressed the importance of systematic treatment of aberrant results. The high level of resolution attempted here, together with the fact that we refrained from a priori deleting measurements from the model unless we had external proof that they were erroneous, means that a certain amount of noise is inevitable. The replication protocol described above can often distinguish between errors generated in the laboratory - which would produce one or more outliers within a replicated set—and archaeological errors, either an out-of-context sample or a misattribution of the 
context. These would be manifest in internally consistent measurements that are out of order with the proposed sequence and would cause a poor fit between the data set and the model. To distinguish between the 2 types of errors, we call the first type "outliers" and the second "misfits" (Sharon et al. 2005:72-73, 77-78).

OxCal v 3.10 (Bronk Ramsey 2005) with atmospheric data from Reimer et al. (2004) provides a heuristic statistic for assessing the quality of the fit of the model, based on the overlap integral between the prior (unconstrained) measurement distribution and the posterior dating distribution (as constrained by the model). The rule of thumb is that an "agreement index" of $60 \%$ or more is a reasonable fit.

The strategy used here is as follows (see Figures 6-8): First, we present the results of the model with all misfitted results. This model usually shows very poor overall fit but has the merit of giving the best possible estimate of the dates of the transitions of interest-noise notwithstanding. Then, we start stepwise removal of misfits, beginning with the ones showing the lowest agreement index, until the overall agreement reaches $60 \%$. We then present the "cleaned" model.

As it happens, the differences engendered by the stepwise removal of misfits, other than a gradual rise in the overall agreement index, were always very minor. Thus, the boundary distributions in both models, with and without the misfits, are always rather close.

\section{RESULTS}

A great number of OxCal runs were performed on the data set. We have 3 different models, and 3 different ways of combining (or not) replicated sets. Each of these 9 runs was repeated once on all types of samples, and once for short-lived samples only. Finally, we present 2 graphs of the results of each run, one before removal of misfits and one after "cleaning" misfitted results. This makes for 36 different assessments of the boundary-distributions between Iron I and Iron II in the Levanttimes two in models where we include the "transitional" category itself and calculate both its beginning and end boundary (Figures 6-8).

The many different runs, under various presuppositions, serve to assess the vulnerability of the results to changes engendered not by the data itself, but the way it may be statistically analyzed. In the best case scenario - the "focused" model with only short-lived samples-we reach a 91\% agreement with the removal of 3 misfits (out of 40 samples). We could have stopped after only 2 removals, but since all 3 had rather low agreement indices (under 10\%) it seemed prudent to remove all of them. The noisiest model, as expected, is the "composite" model including long-lived charcoal samples. After the removal of 29 misfits (out of 103), the overall agreement index reached 56\%. Almost one-third of the observations are misfitted. This is a rather high proportion. However, most of these do not relate to the boundaries of interest at all (but are, for example, too old to be in the Iron I at all, or misfitted vis-à-vis the Iron IIA|B transition). Also, a rather high proportion of the wood-charcoal samples turned out, in retrospect, to be indeed too old for their context (11 out of 25 charcoal samples in this study).

Figures 6-8 summarize the modeling runs. Each model includes the boundary distributions between Iron I and Iron II. Those models that include "transitional Iron I|II" contexts as a separate phase have two superimposed distributions on them. Also indicated are (40-yr-wide) acceptance regions for the alternative hypotheses regarding the Iron I|II transition: 1015-975 BCE for the High Chronology and 925-885 BCE for the Low to hyper Low. These are based on the differing historical backgrounds currently offered for the archaeological transition: Davidic conquests (dated by the Bible to the 1015-975 BCE region) by the High Chronology vs. the aftermath of the Shoshenq I campaign (about 925 BCE) by the Low Chronology. 

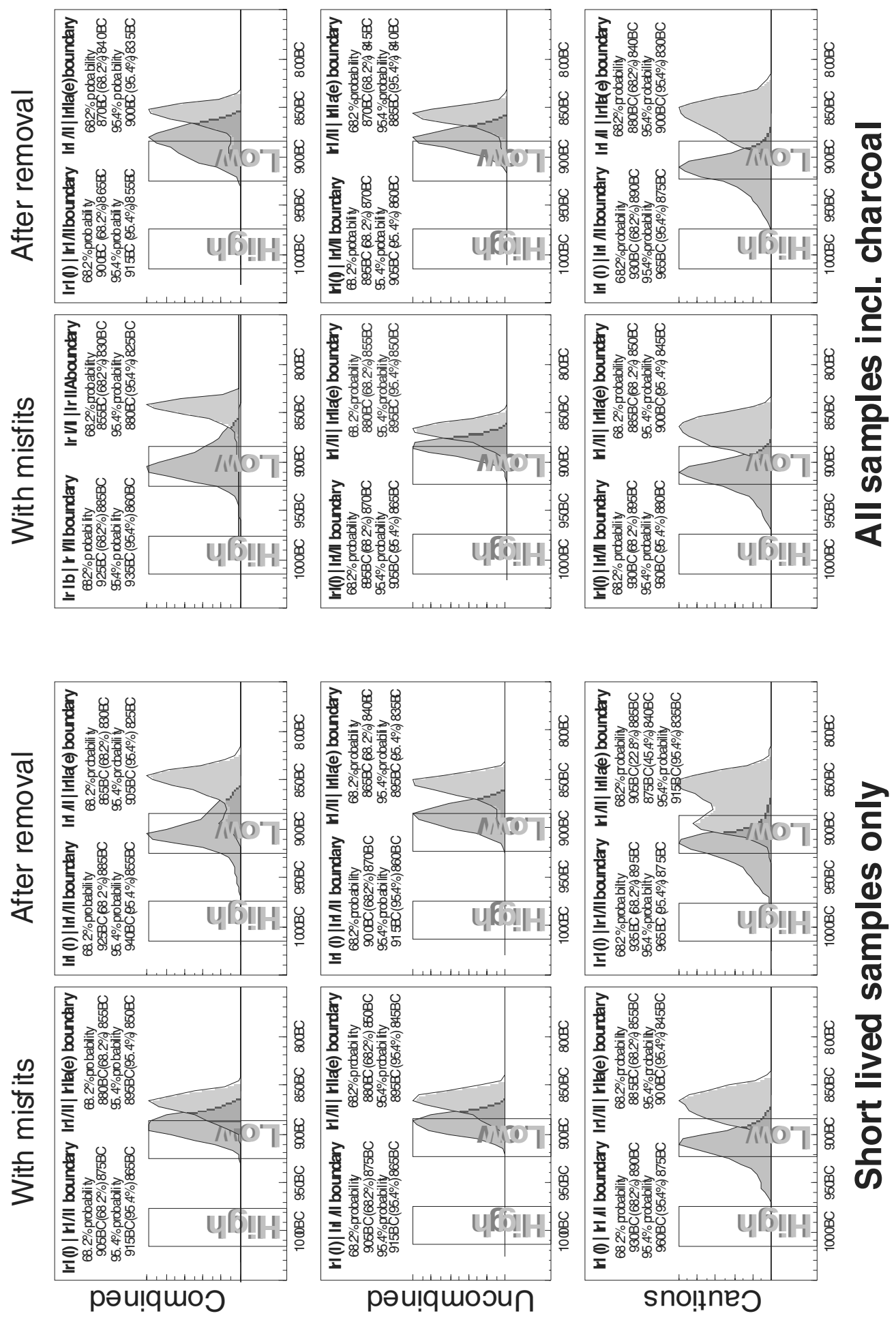

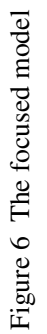



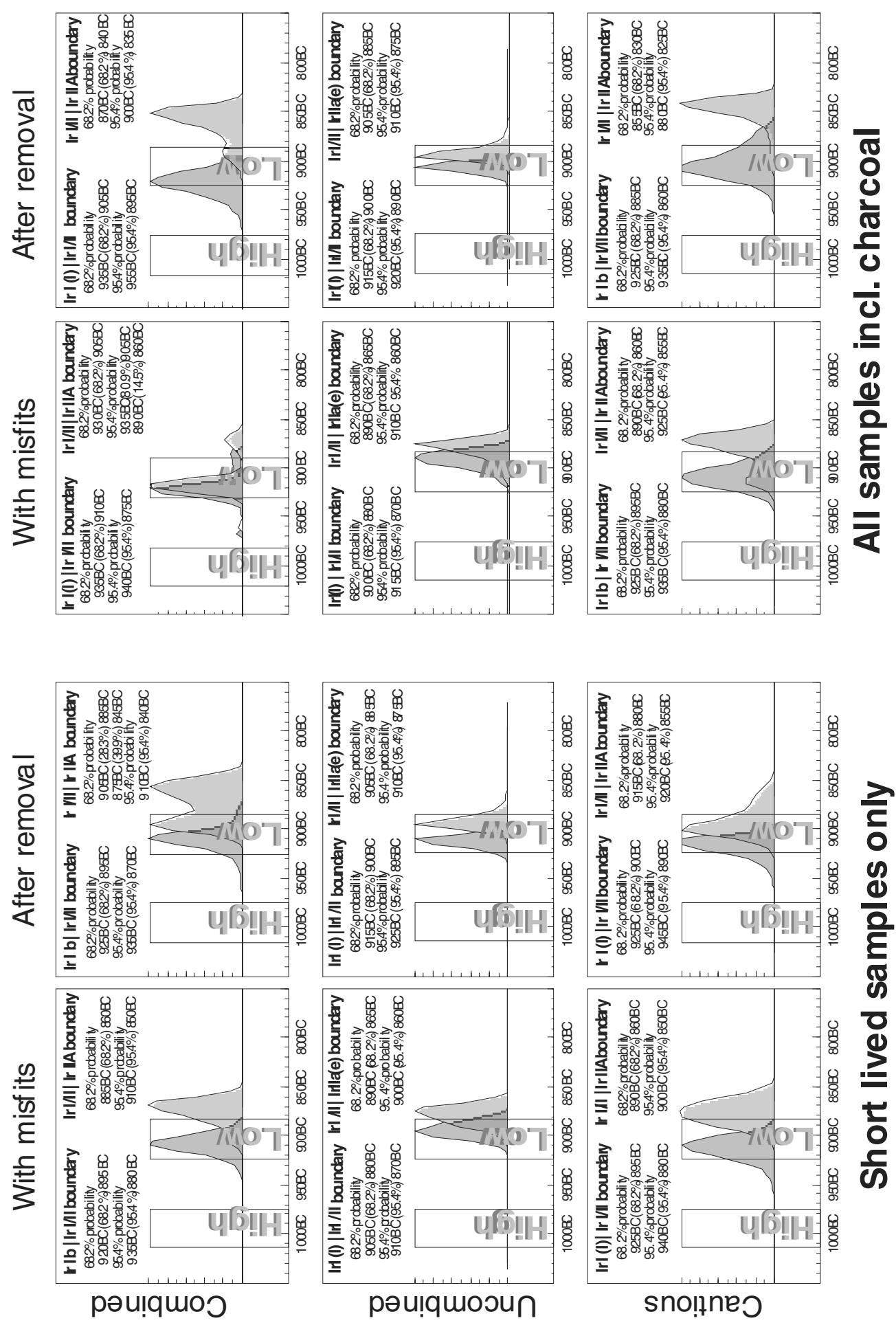

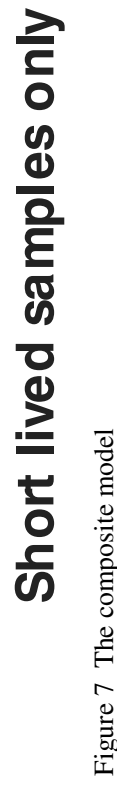



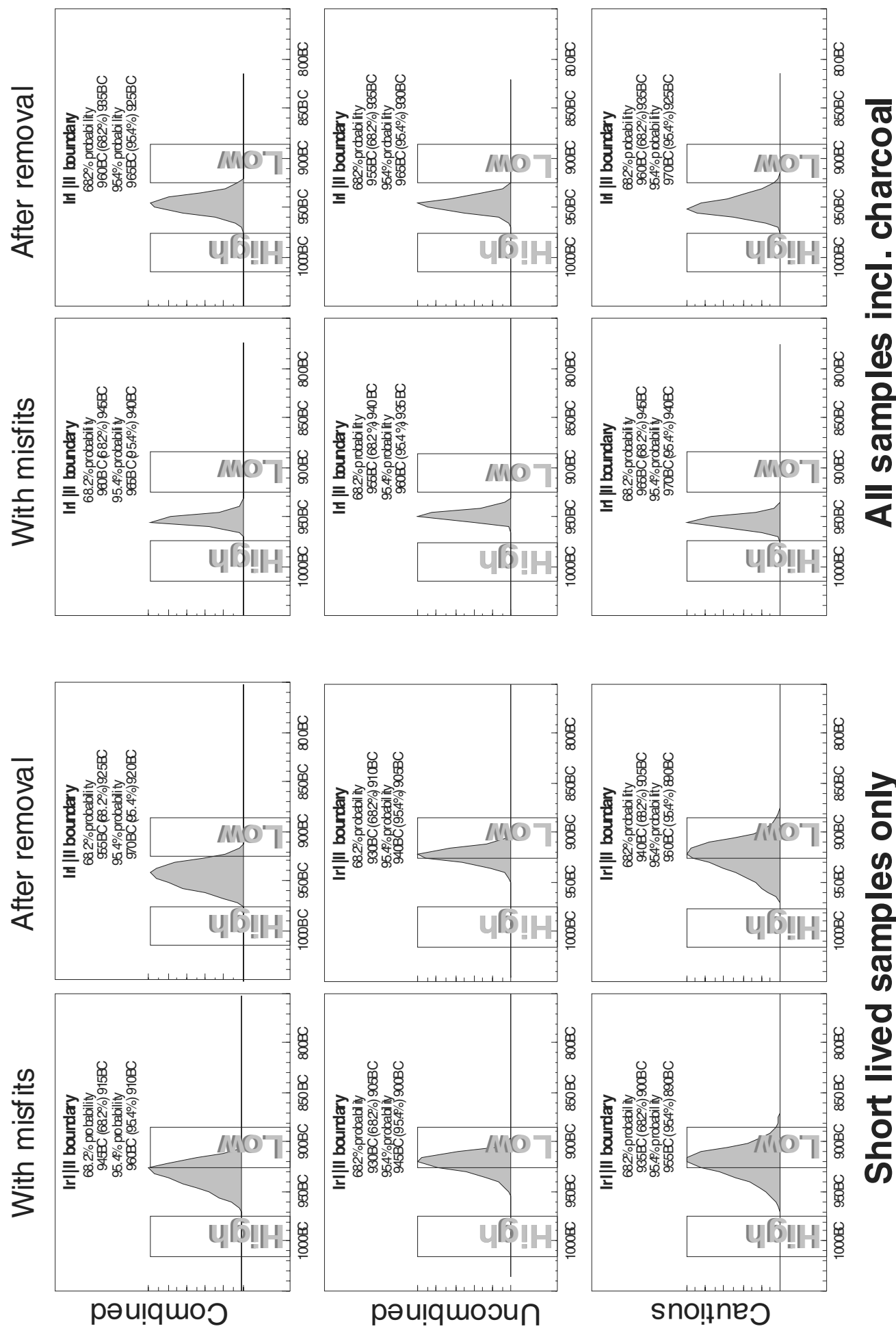

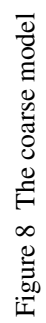


Clearly, the choice of model and statistical treatment does affect the results, in the extreme case by as much as a century. The highest "transition" dates we got (the "coarse" model with charcoal) puts the transition at about 950, while the lowest possibilities (e.g. the "composite" model uncombined) put the Iron I (late) | Iron I|II boundary at about 890 and the Iron I|II | Iron IIA boundary at about 850 BCE. Typically, though, the models differ by a few decades at most, and this variability is over the 900-850 range. The highest "transition" date was reached by the "coarse" model, using a general division to Iron I contexts vs. Iron II and ignoring the critical transitional contexts, as well as including all the charcoal samples with the concomitant old-wood effect. But even in this extreme case, we get a transition in the mid-10th century, in between the 2 hypotheses. In all other model runs, the results hover around the Low Chronology range, with a transition between Iron I and Iron II around the turn of the 10th century. The "conventional"/"High" chronology (i.e. the "real" transition being at $980 \mathrm{BCE}$ or earlier) is completely excluded by all models.

The results are also clearly dependent on the (relatively few) dates in the actual transitional (Iron I|II) range, as well as the highest dates in the early Iron IIA contexts and the lowest ones in the latest Iron I contexts. To investigate this dependence, we performed the following simple test. As the controversy now centers on the 10th century, we examined only those assays that produce distributions that are largely within the 10th century BCE. This was performed using only the 40 samples of the focused model (only short-lived samples from late Iron I, transitional Iron I|II, and Iron IIA contexts). Of these dates, the 10th century is occupied mainly by ones of late Iron I and "transitional" contexts (Table 6A), and this is true even when only the second half of that century is taken into account (Table 6B).

Table 6 A) Number of late Iron I, transitional Iron I|II, and Iron II combined dates (of short-lived samples only in the focused model) whose main distributions fall in the 10th century BCE. B) The same for the latter part of the 10th century. "Earlier than X" means that the $1-\sigma$ range is entirely above X, and the same for "later than Y."

\begin{tabular}{lllc}
\hline (A) & Earlier than 980 & 10th century & Later than 920 \\
\hline Iron I (late) & 8 & 10 & 3 \\
Iron I|II & 0 & 3 & 1 \\
Iron IIA & 0 & 2 & 13
\end{tabular}

\begin{tabular}{lllc} 
(B) & Earlier than 940 & Late 10th century & Later than 910 \\
\hline Iron I (late) & 9 & 10 & 2 \\
Iron I|II & 0 & 3 & 1 \\
Iron IIA & 0 & 3 & 12 \\
\hline
\end{tabular}

Will the inclusion of further results (e.g. already published results of other studies, or the second part of our own, or yet other dates that will undoubtedly be collected) critically tip the scale? It is hard to prophesy. For now, they point squarely within the Low Chronology. To see how much leeway there may be, we should also take a parting look at the calibration curve (Figure 1). The critical question is whether the small downwards wiggle at $\sim 965$ is in the Levantine Iron Age I, as we claim here, or in the Iron Age IIA range, as claimed by Mazar et al. Dates in the 2800-2850 BP range taken from Iron II contexts are needed to establish the High Chronology, while any additional dates in the 27902750 range from Iron I contexts will strengthen the Low one. If future dates prove similar to the ones hitherto obtained (by all projects), the transition dates will continue to hover within the second half of the 10th century BCE to the beginning of the 9th. For the United Monarchy debate, such dates 
will vindicate the assumptions of the Low Chronology, because starting Iron II at any point after about $975 \mathrm{BCE}$ concedes that there is something flawed either in the biblical chronology, or its recount of events, or in the traditional link between material culture change and political history.

The results presented here were obtained using a much more comprehensive approach than previous works (Gilboa and Sharon 2001; Sharon 2001; Bruins et al. 2003; Mazar et al. 2005). The most important and, we hope, enduring result of this study is the large data set (Tables 7, 8), which, however interpreted, will serve as a basis for future chronologies of the Iron Age in the Levant and around the Mediterranean. We introduced here a replication protocol and rigorous methods of identifying and treating outliers. We used a regional approach and ceramic seriation to correlate the different contexts. Based on this, we tested many different models to assess the robustness of the data set and the models themselves. We did not try to date a single "historical event" but to introduce a series of transitions to help situate the temporal position and duration of phases in the archaeological record. Finally, we did not try to hide or explain away any of the misfits. All the dates-those that agree with the chronological framework proposed and those that contradict it-are herein presented.

Unlike historical dating, both ${ }^{14} \mathrm{C}$ and seriation are augmentative, progressive (in the sense that new and better data are continuously added), and probabilistic. Archaeologists relying on probabilistic tools will have to settle for probabilistic answers that indicate the highest likelihood for a given state-of-the-art. For the time being, our data set is definitely on the side of the Low Chronology and demonstrates that the Iron Age I|II transition occurred about the end of the 10th century BCE.

We have now entered the second stage of the Iron Age Dating Project. It involves the addition of many new dates to the database, mainly from recent excavations (but this time we use only clusters of short-lived samples), quality control on past and future samples using Raman spectroscopy (Alon et al. 2002), and the involvement of other laboratories. Inevitably, we believe, this is the only way to overcome the impasse regarding early Iron Age chronology in Israel.

\section{ACKNOWLEDGMENTS}

This research is being carried with the support of the Israel Science Foundation (grants Nos. 778/00; 141/04), the Kimmel Center of Archaeological Sciences at the Weizmann Institute of Science, the Research Authority at Hebrew University, the Research Authority at the University of Haifa, and the US National Science Foundation (Grant EAR01-15488). The first Tel Dor set of dates was produced in the 1990s by Israel Carmi, then director of the Rehovot laboratory. We are grateful for the full cooperation of all the excavators who contributed the samples for the project, from the following sites: Tell el-Akhwat (A Zertal), Aphek (M Kochavi and Y Gadot), Bethsaidah (R Arav), Beth Shemesh (S Bunimovitz and Z Lederman), Dor (E Stern), Tel Hadar (M Kochavi and E Yadin), Tell el-Hamma (J Cahill), Hazor (A Ben Tor), Hebron (E Eisenberg and the Israel Antiquities Authority), Tell Keisan (J-B Humbert), Megiddo (I Finkelstein, D Ussishkin, and B Halpern), Tel Miqne-Ekron (T Dothan and S Gitin), Moza (A De Groot, Z Greenhut, and the Israel Antiquities Authority), Tell Qasile (A Mazar), Tel Rehov (A Mazar), Kh Rosh Zayit (Z Gal and the Israel Antiquities Authority), Tell es-Safi-Gath (A Maeir), Shiloh (I Finkelstein), Sulem (Y Alexandre and the Israel Antiquities Authority), Yoqne'am (A Ben-Tor), and Tel Zayit (R Tappy). We wish to thank J van der Plicht of the Center for Isotope Research at Groningen for his cooperation in the intercomparison exercise regarding the Dor and other samples. Talia Goldman of the Hebrew University was of invaluable assistance in selecting the Tel Dor samples. We wish to specially thank Eugenia Mintz for the incredible and careful work done for the preparation of all the samples measured in this project. 


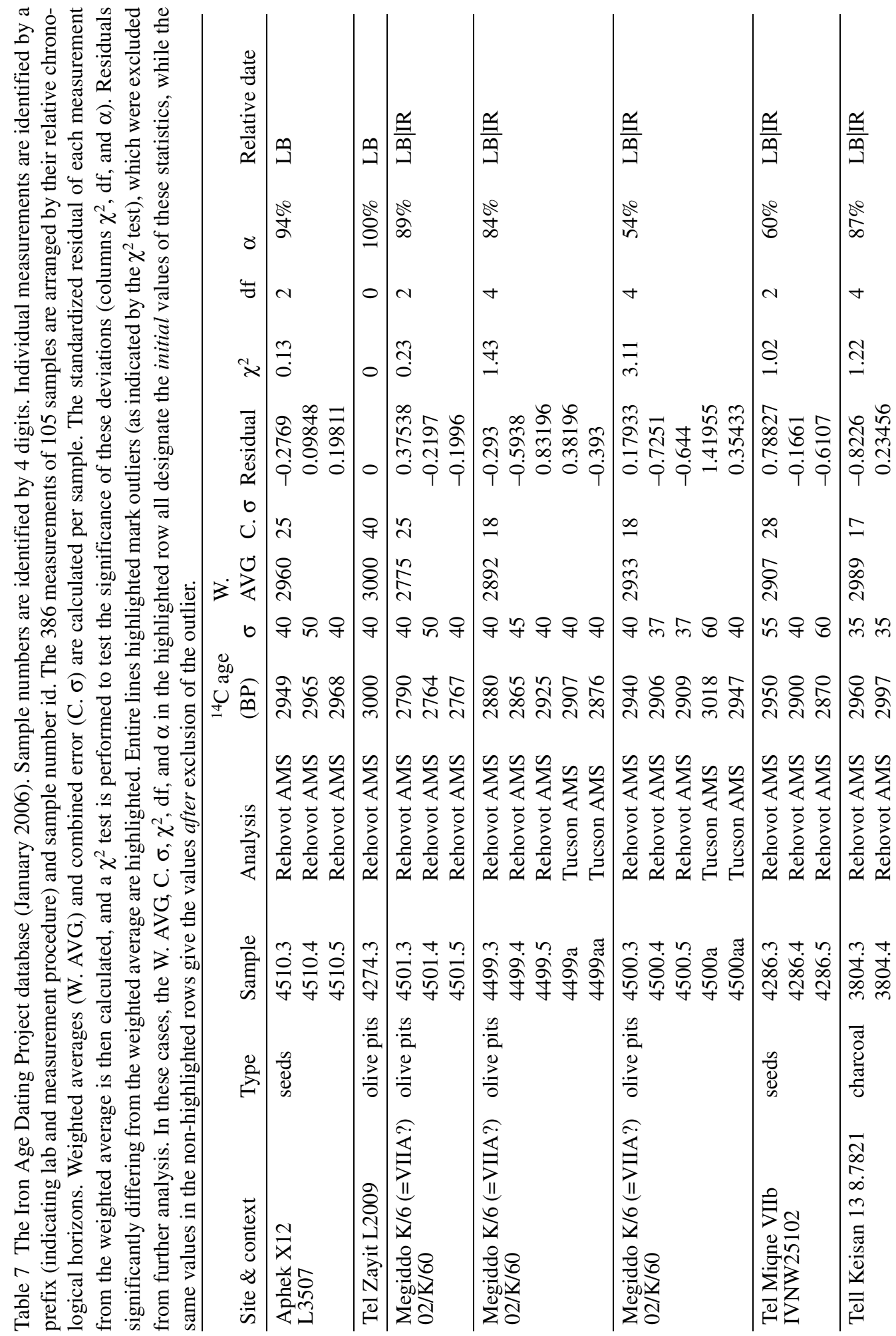




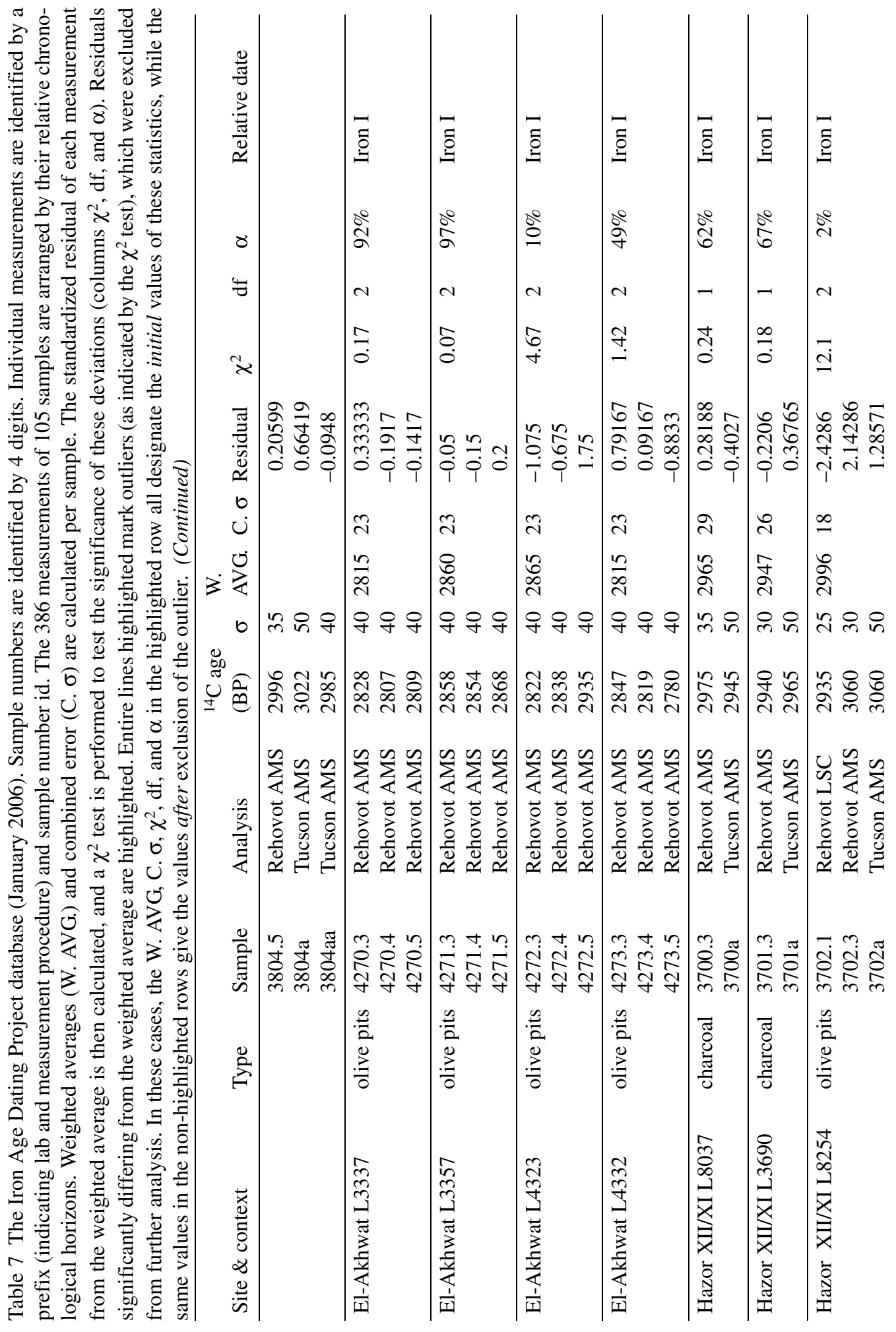




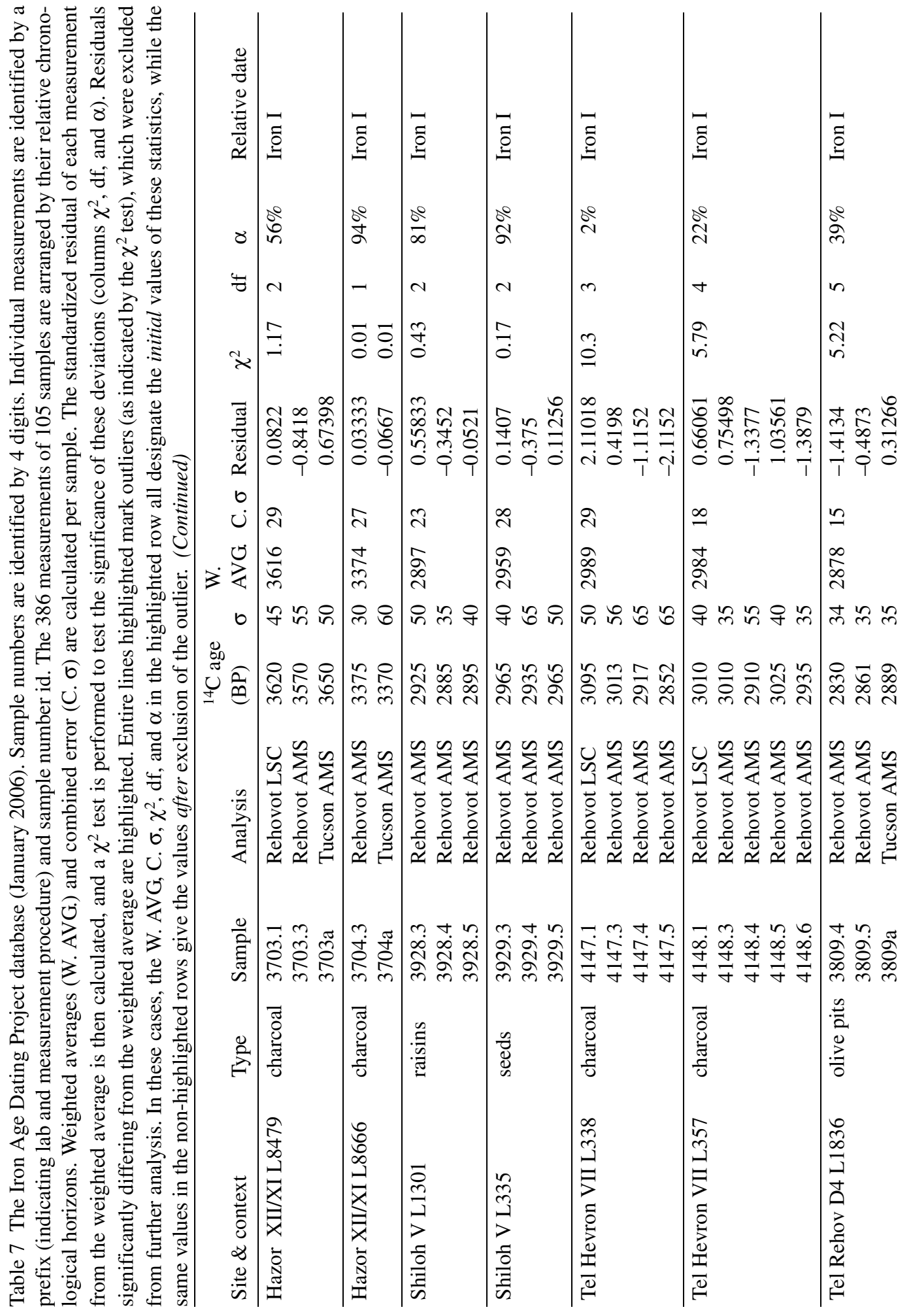




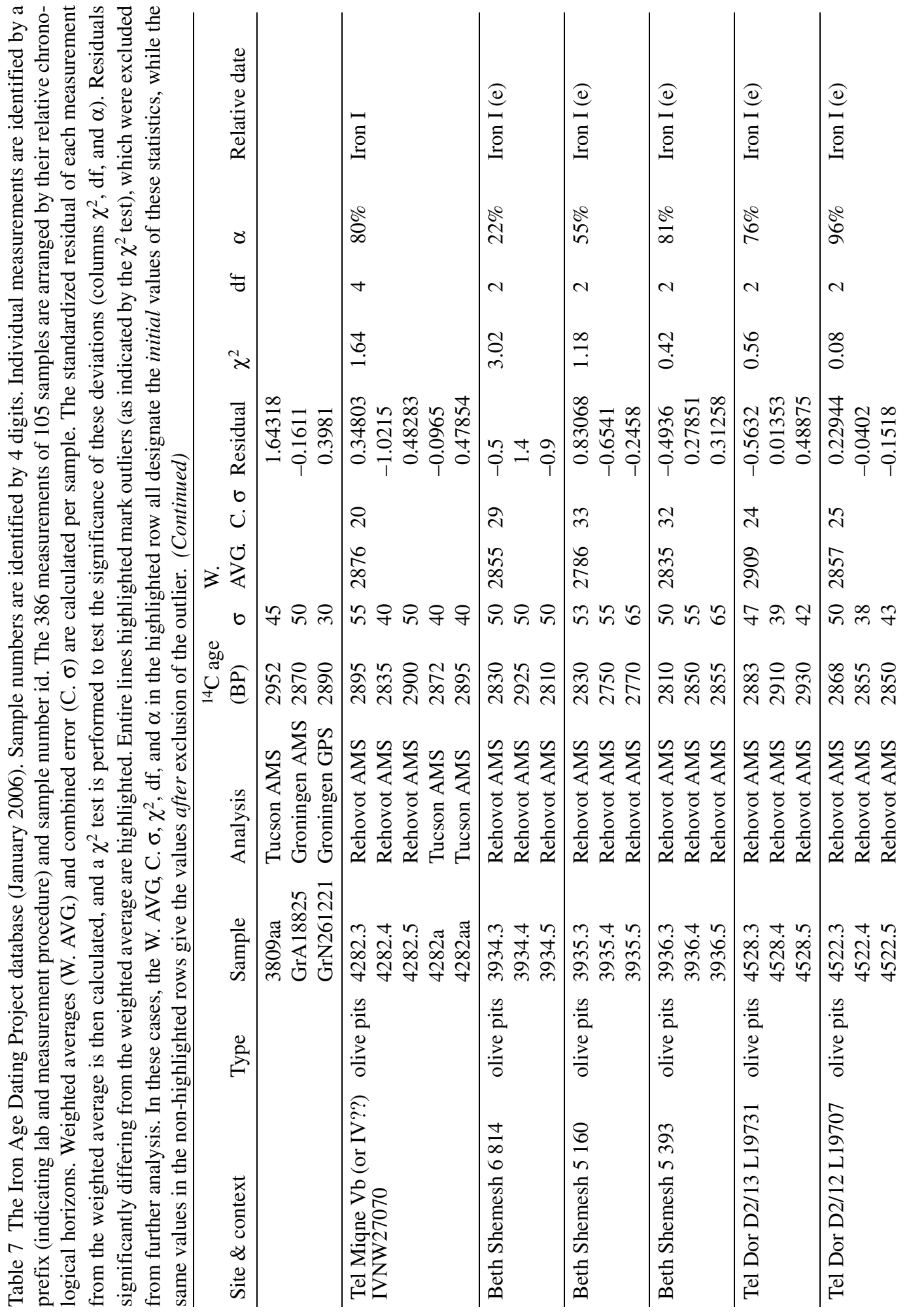




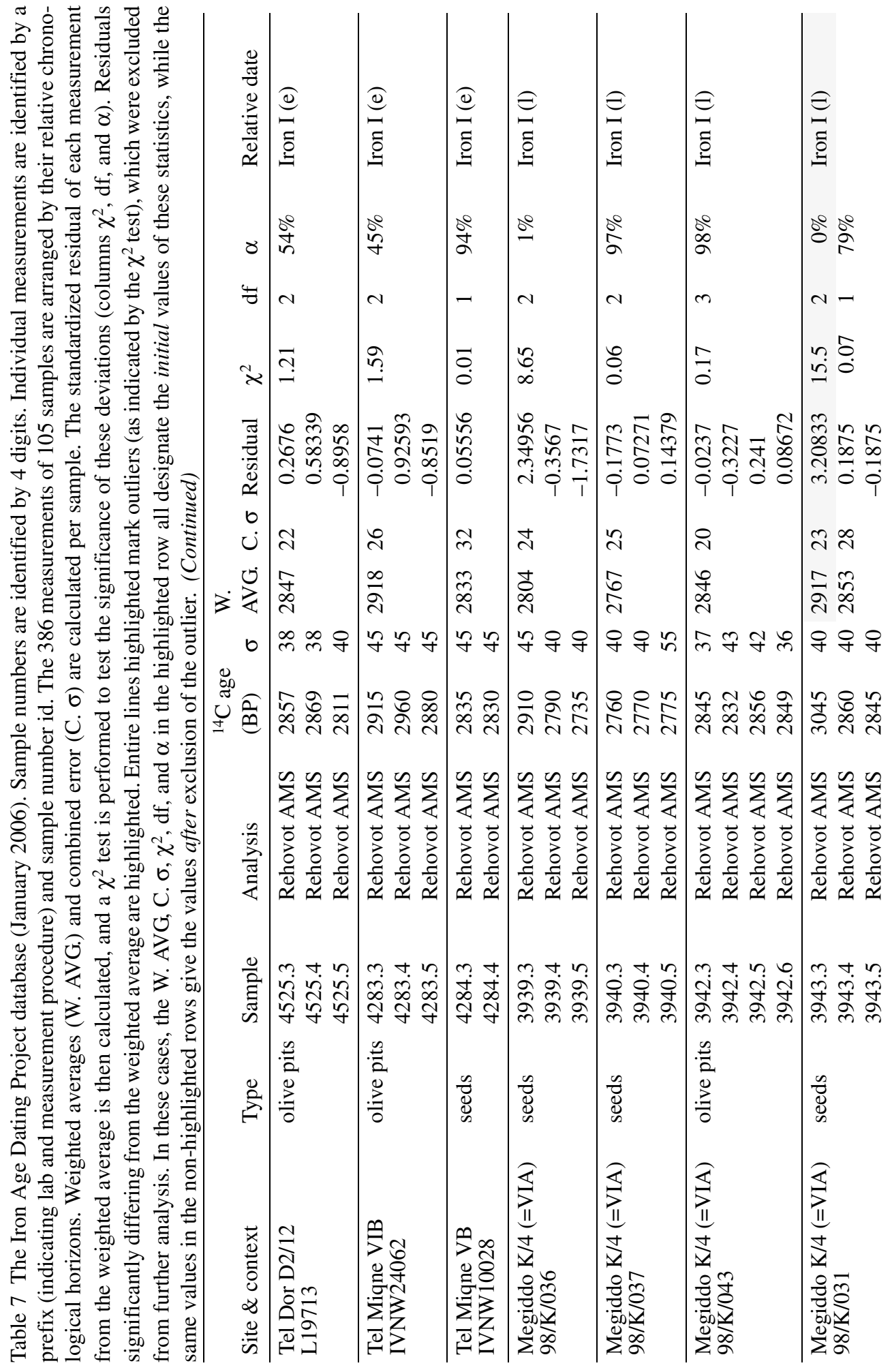




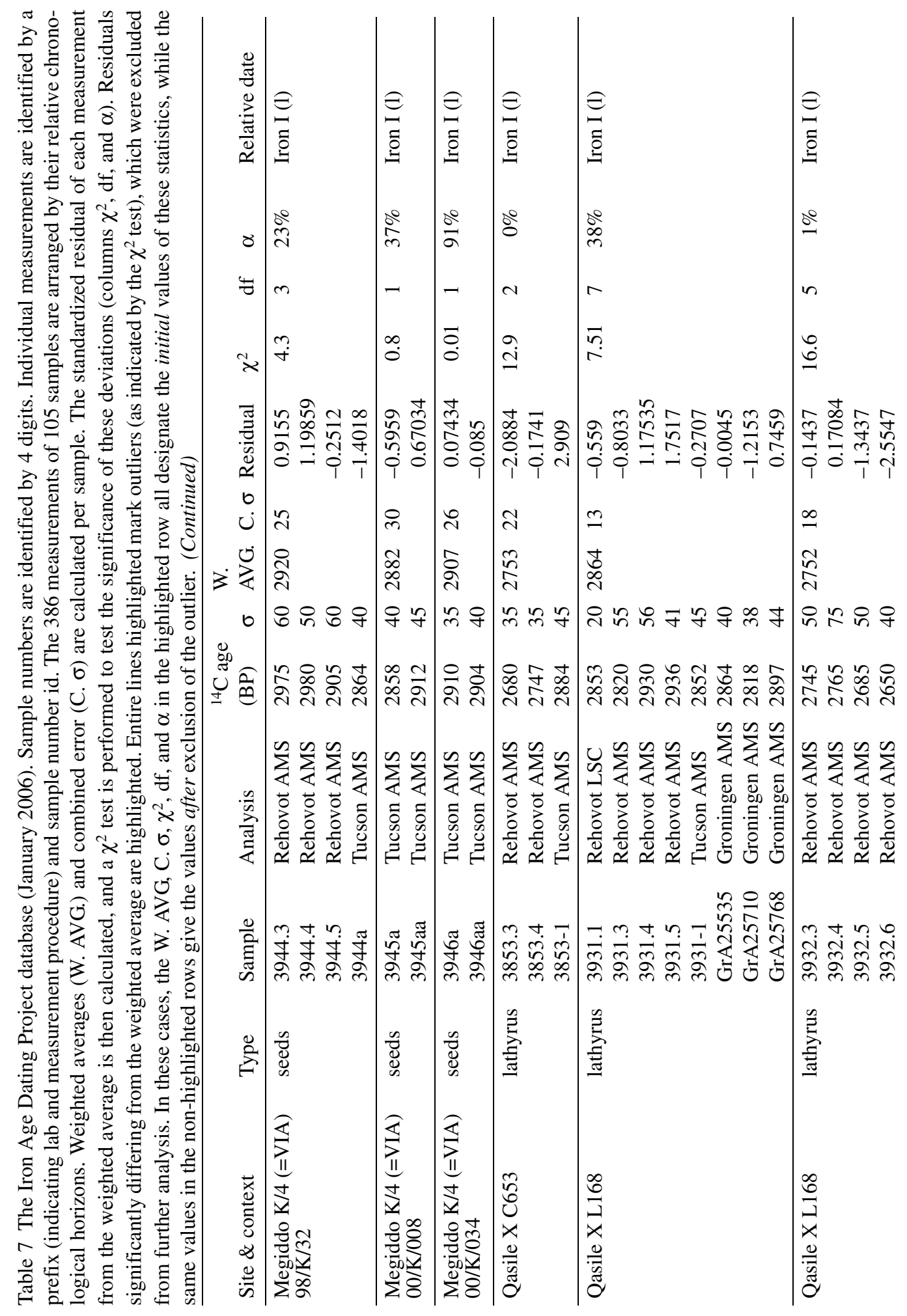




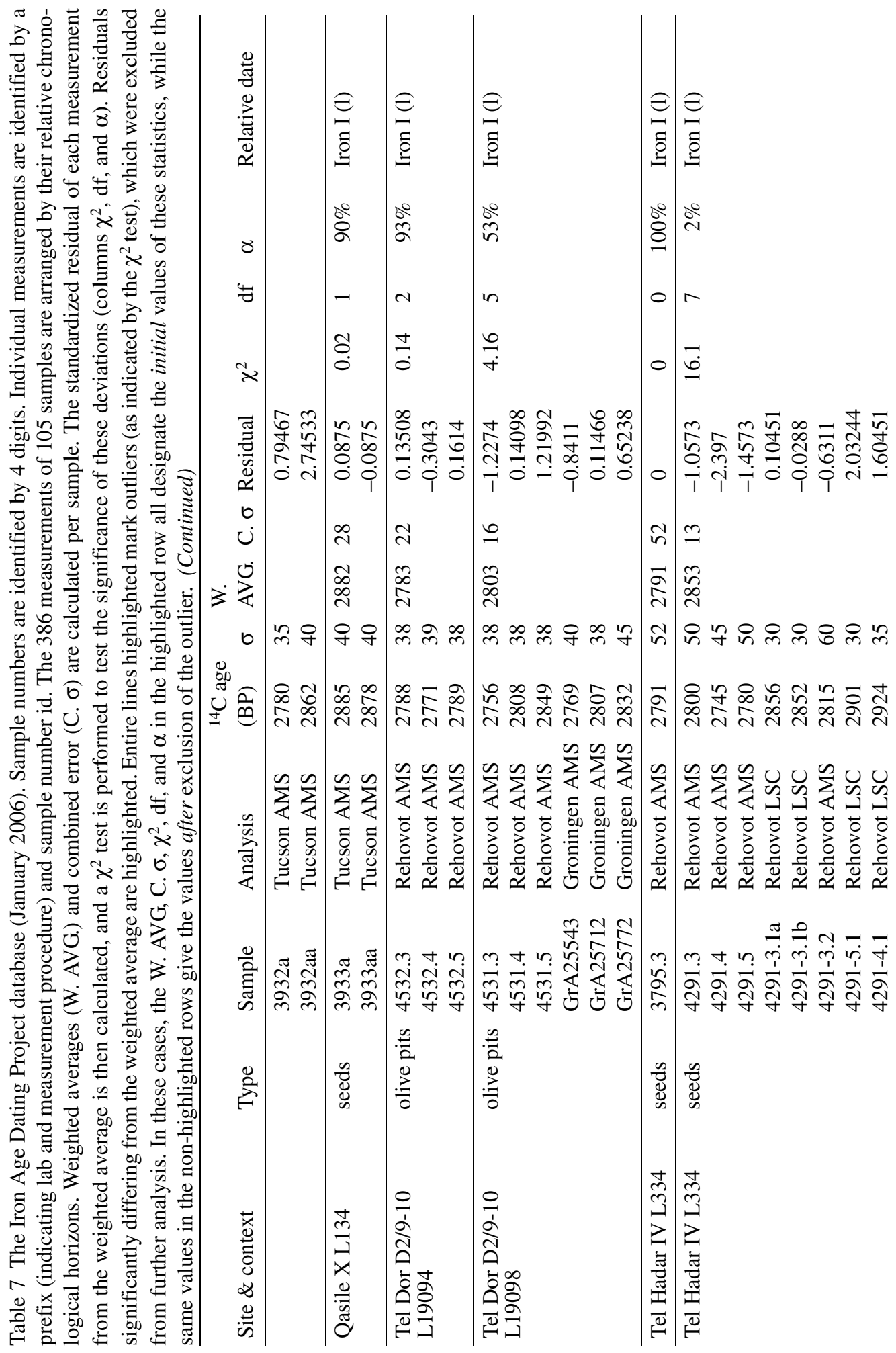




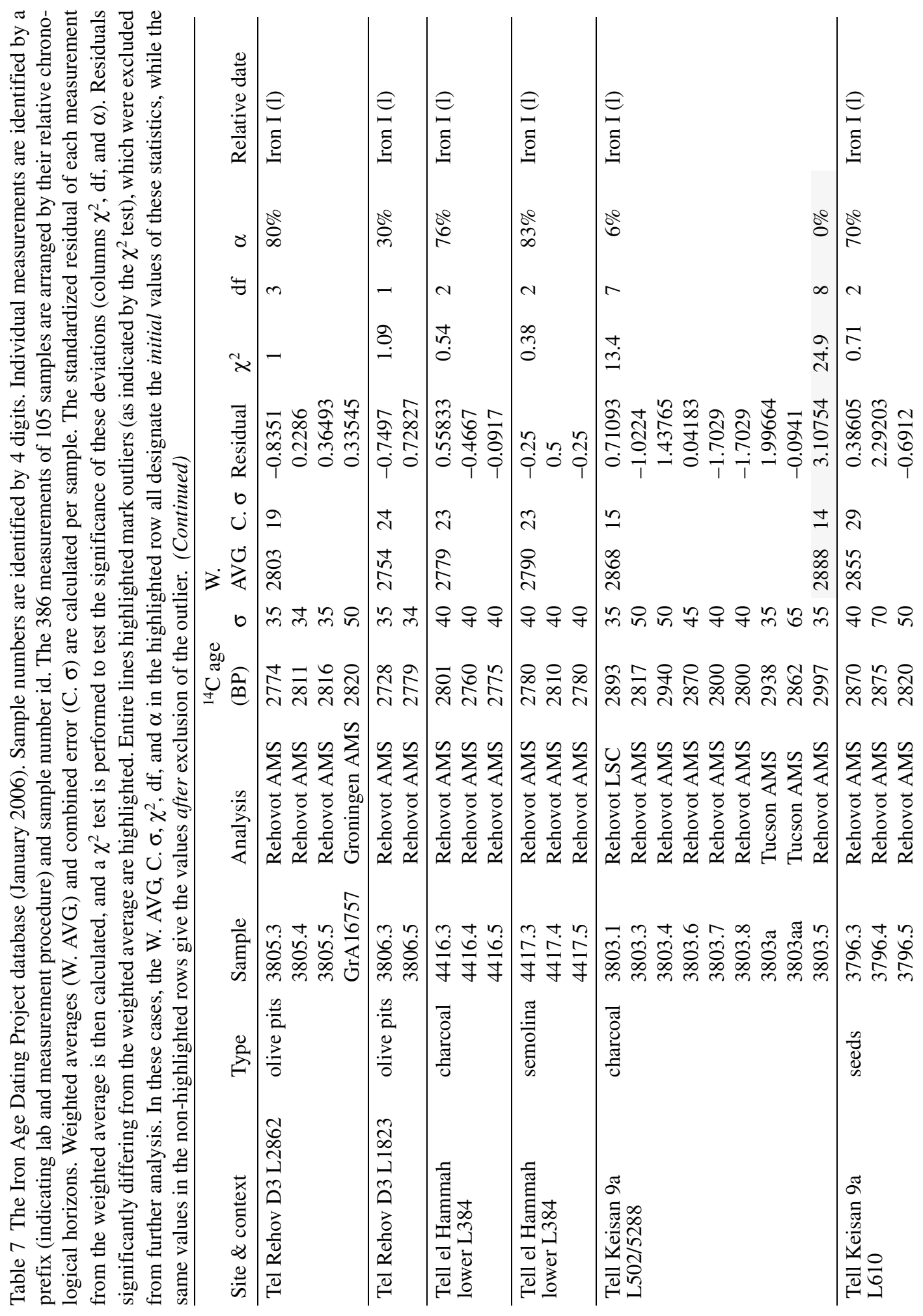




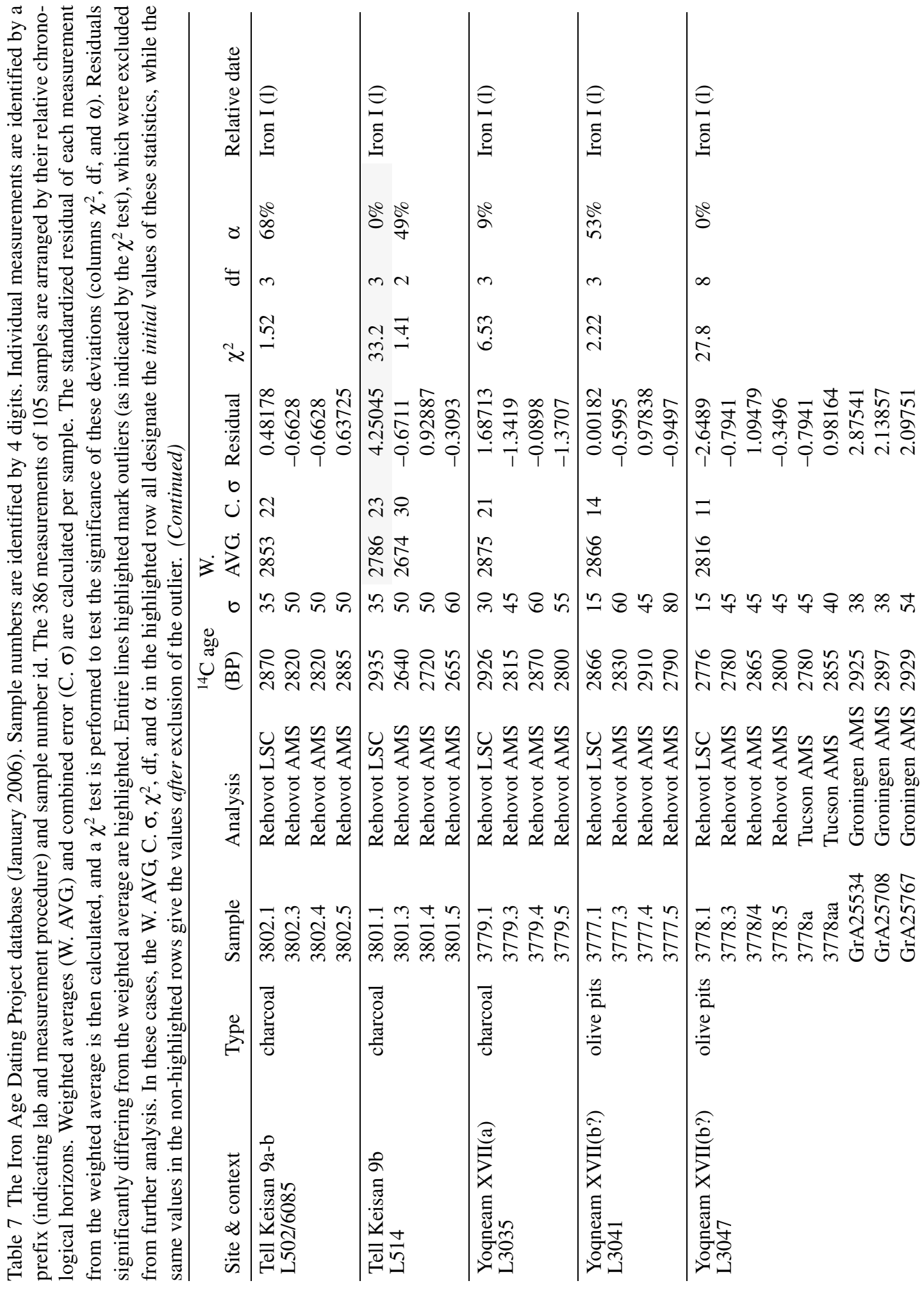




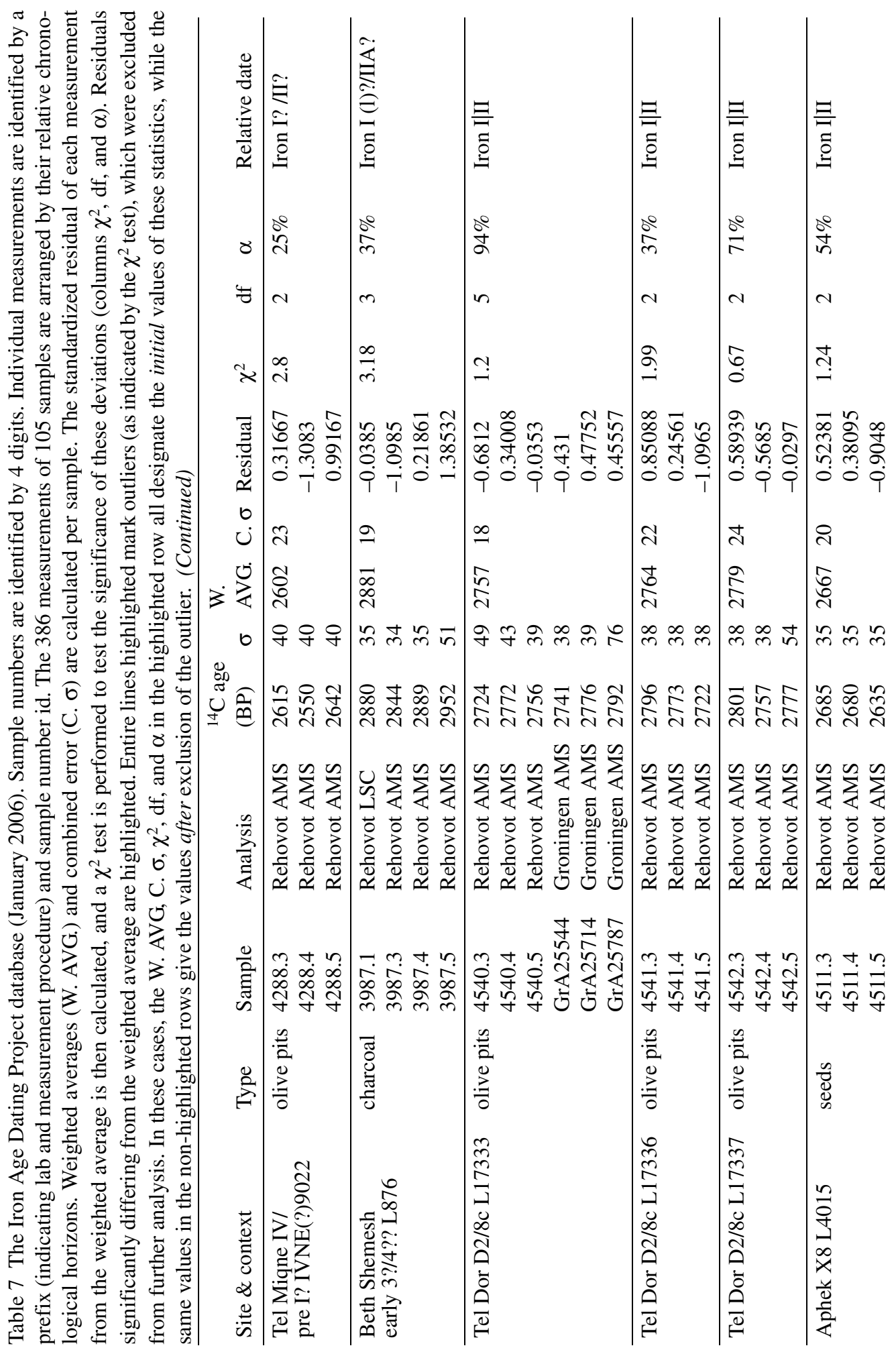




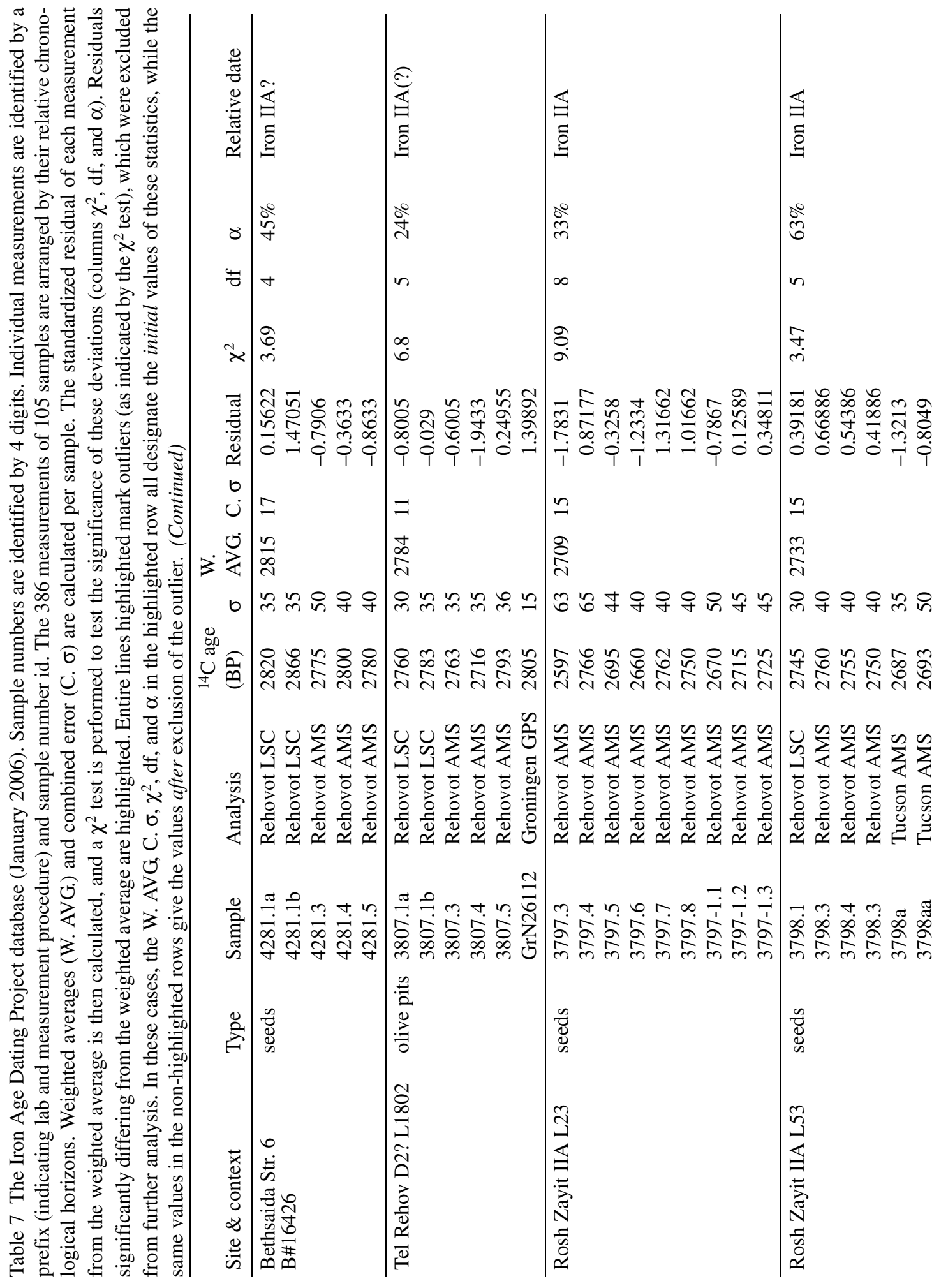




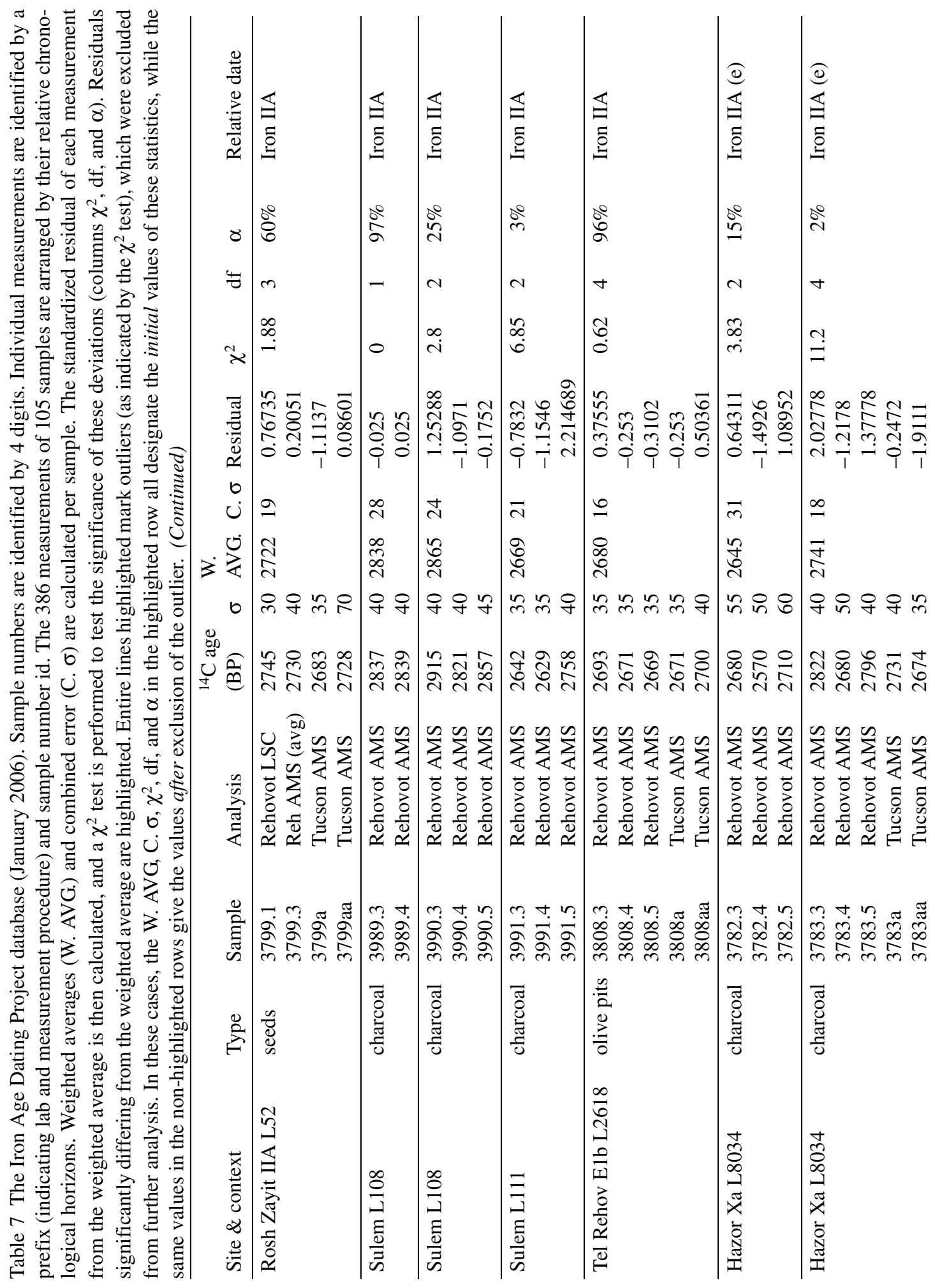




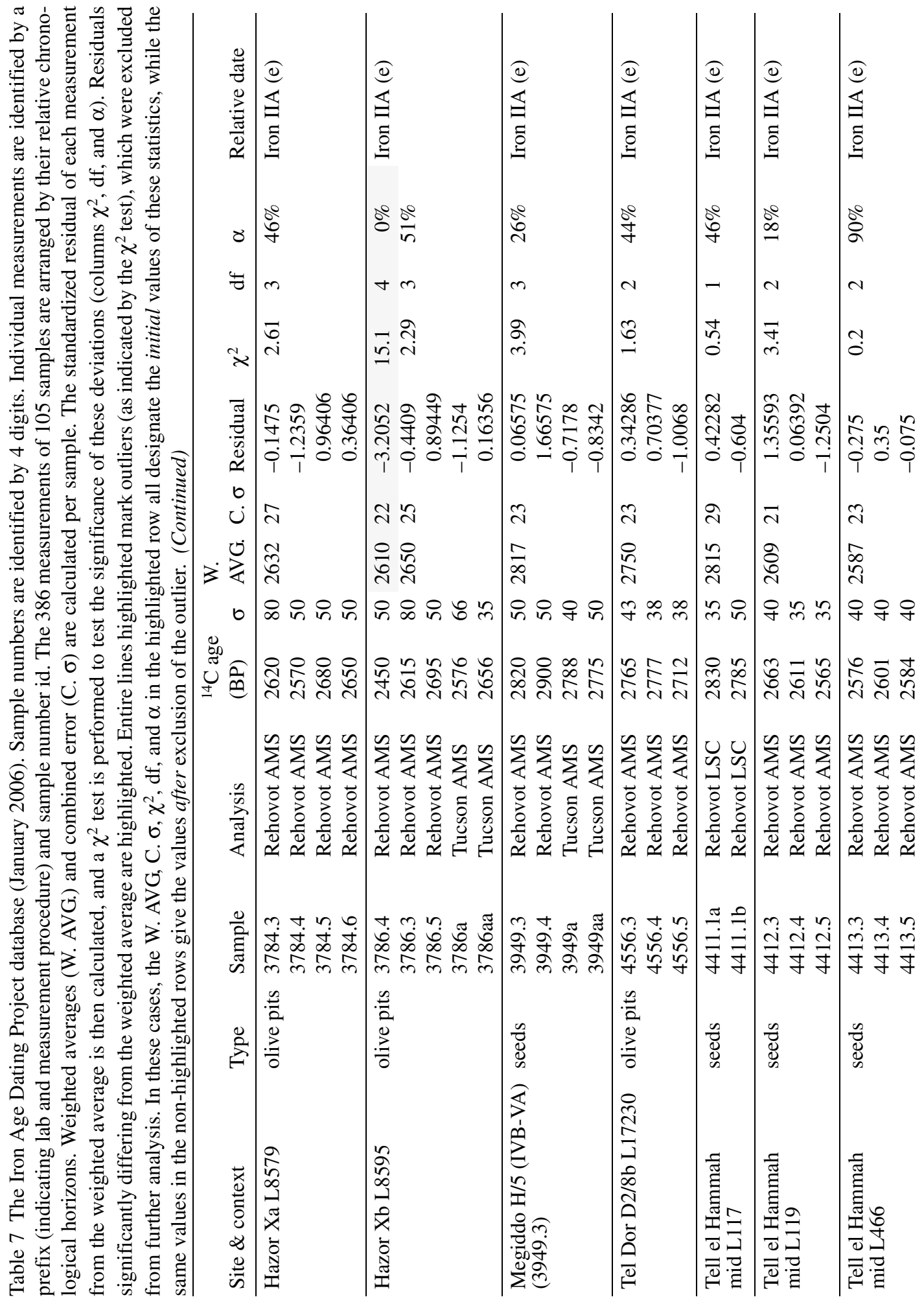




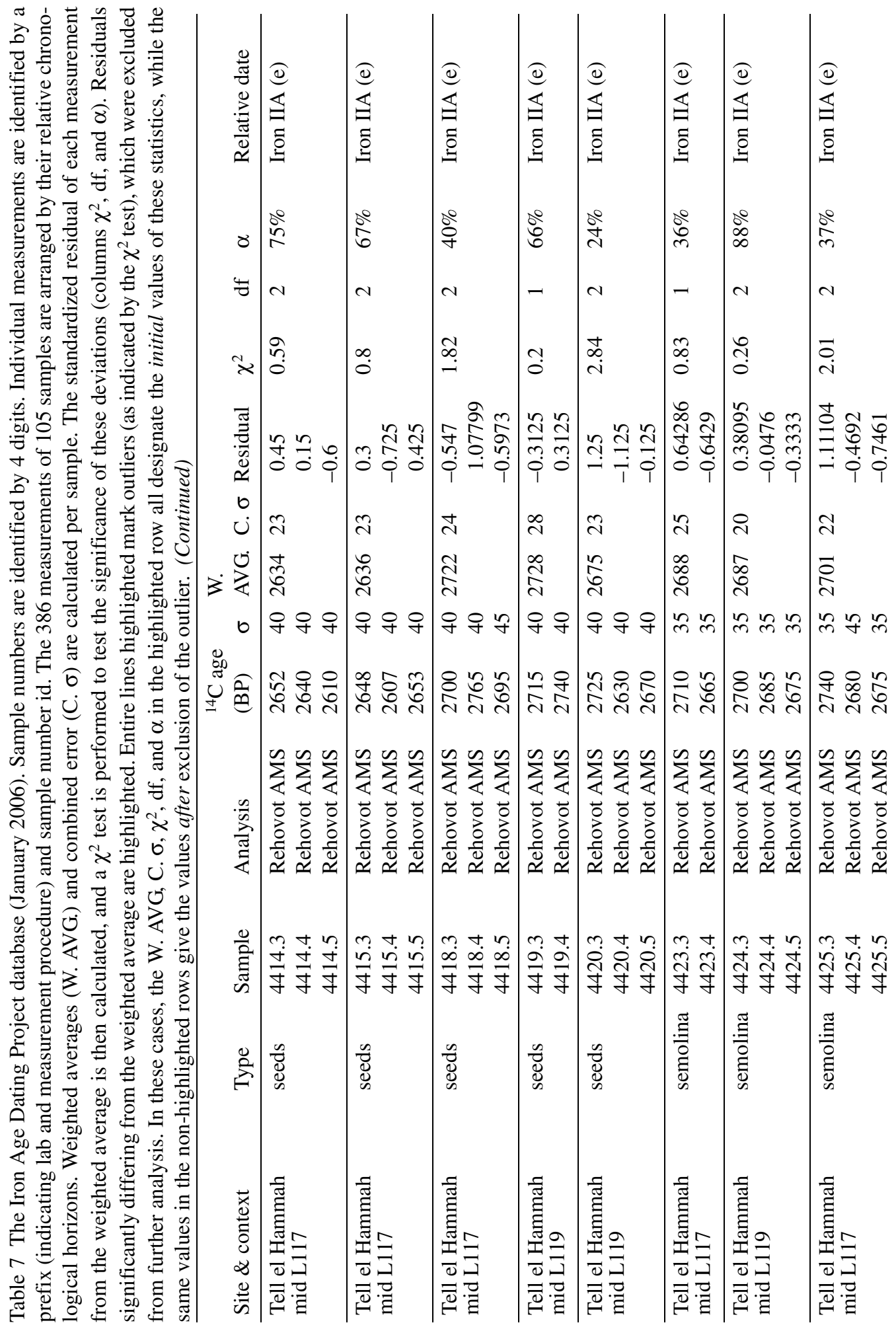




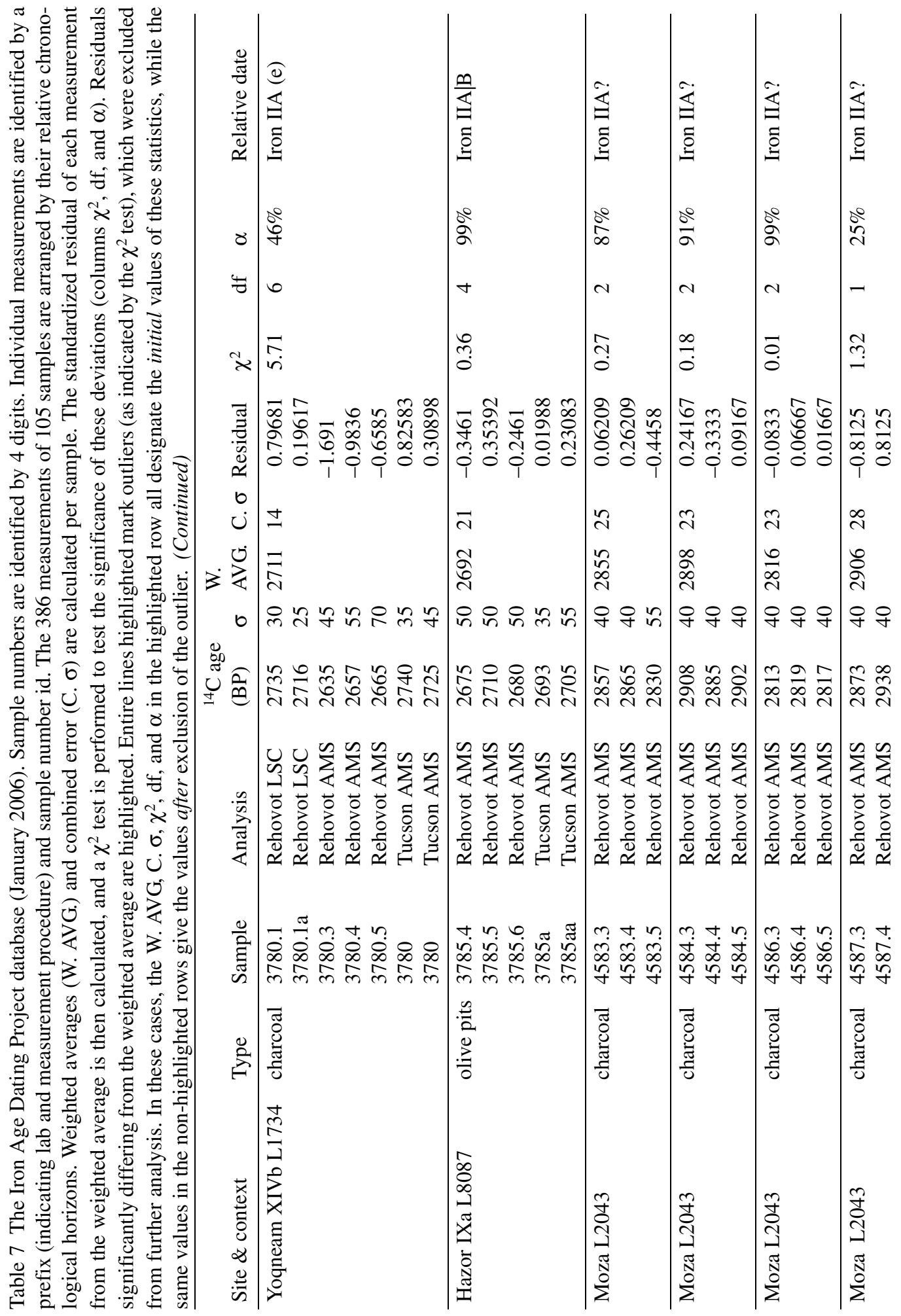




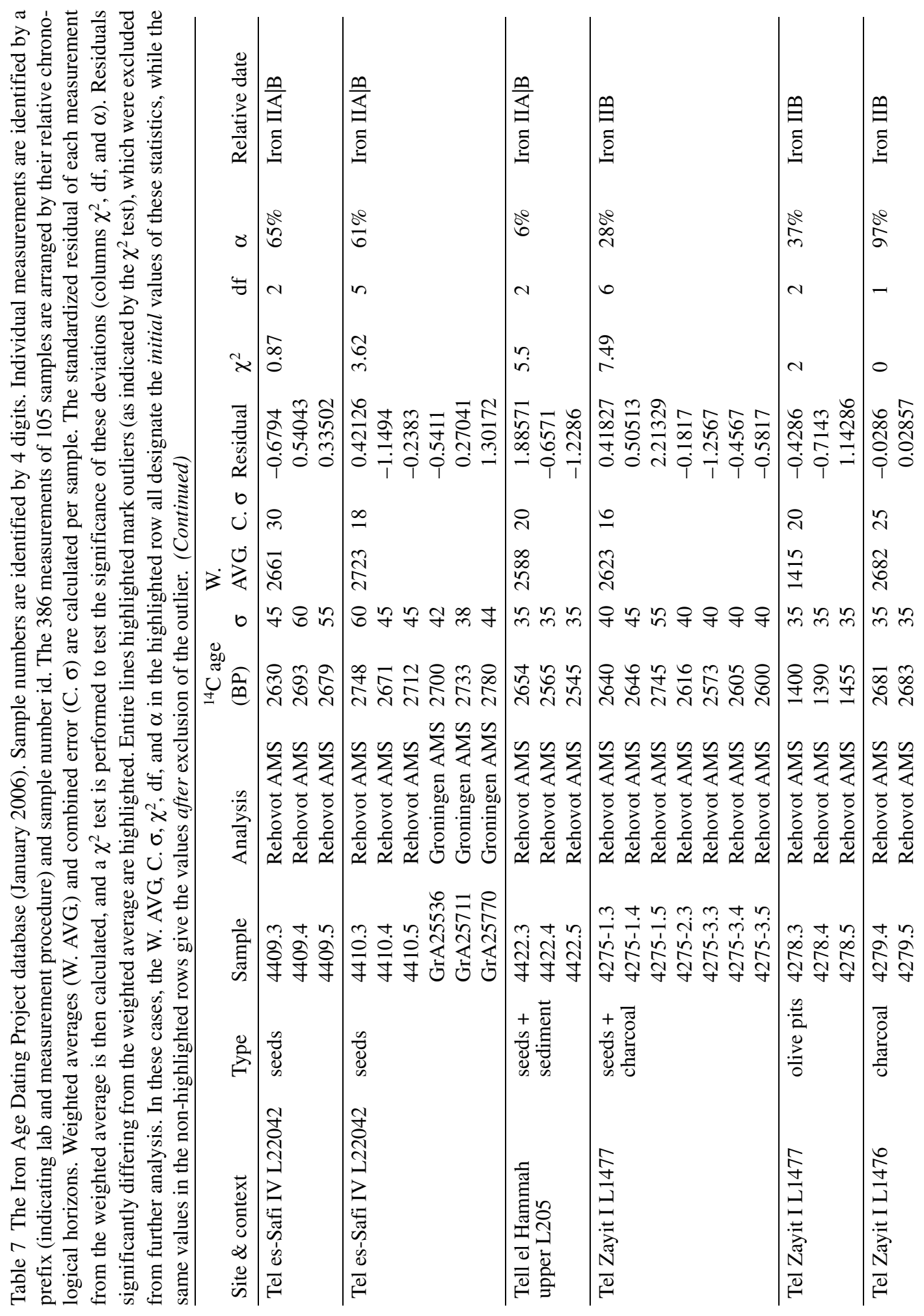




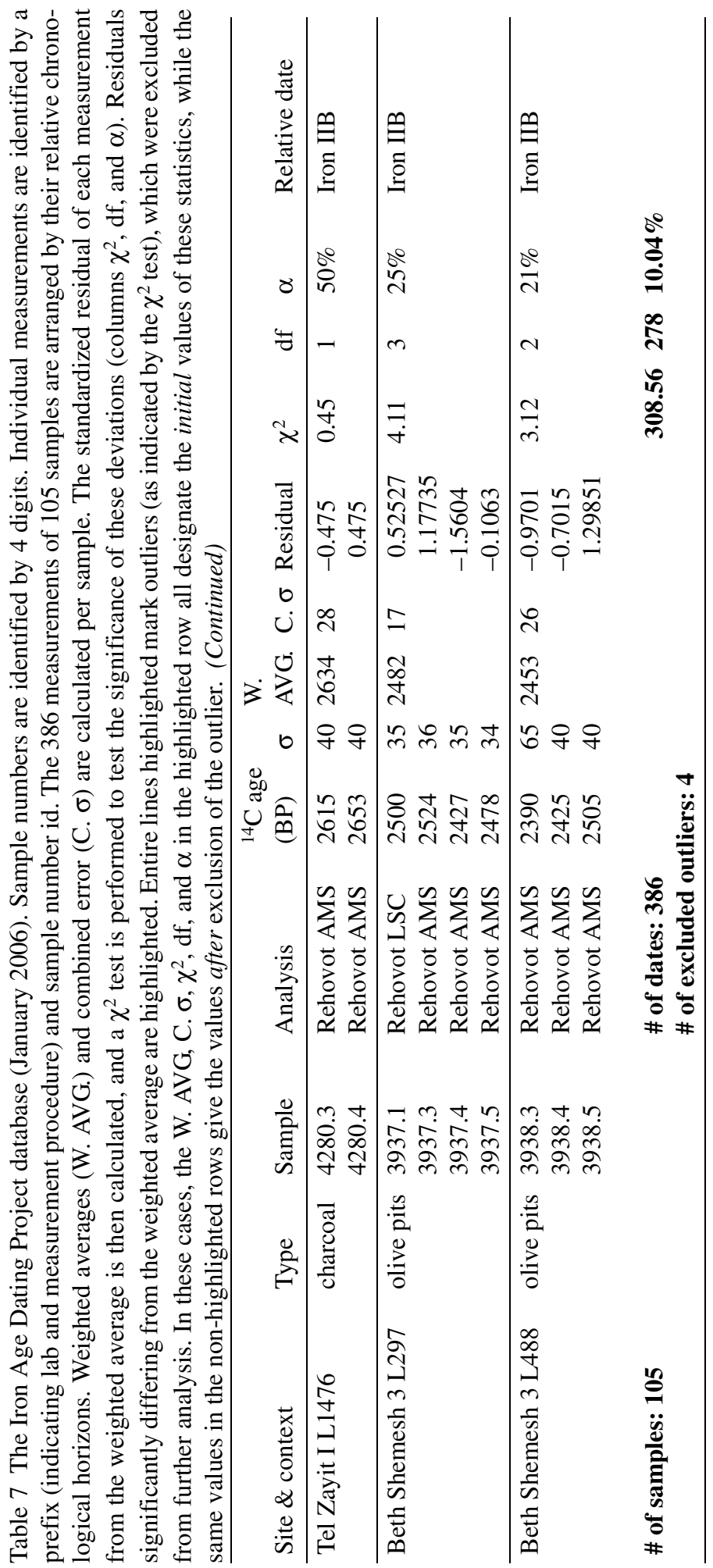




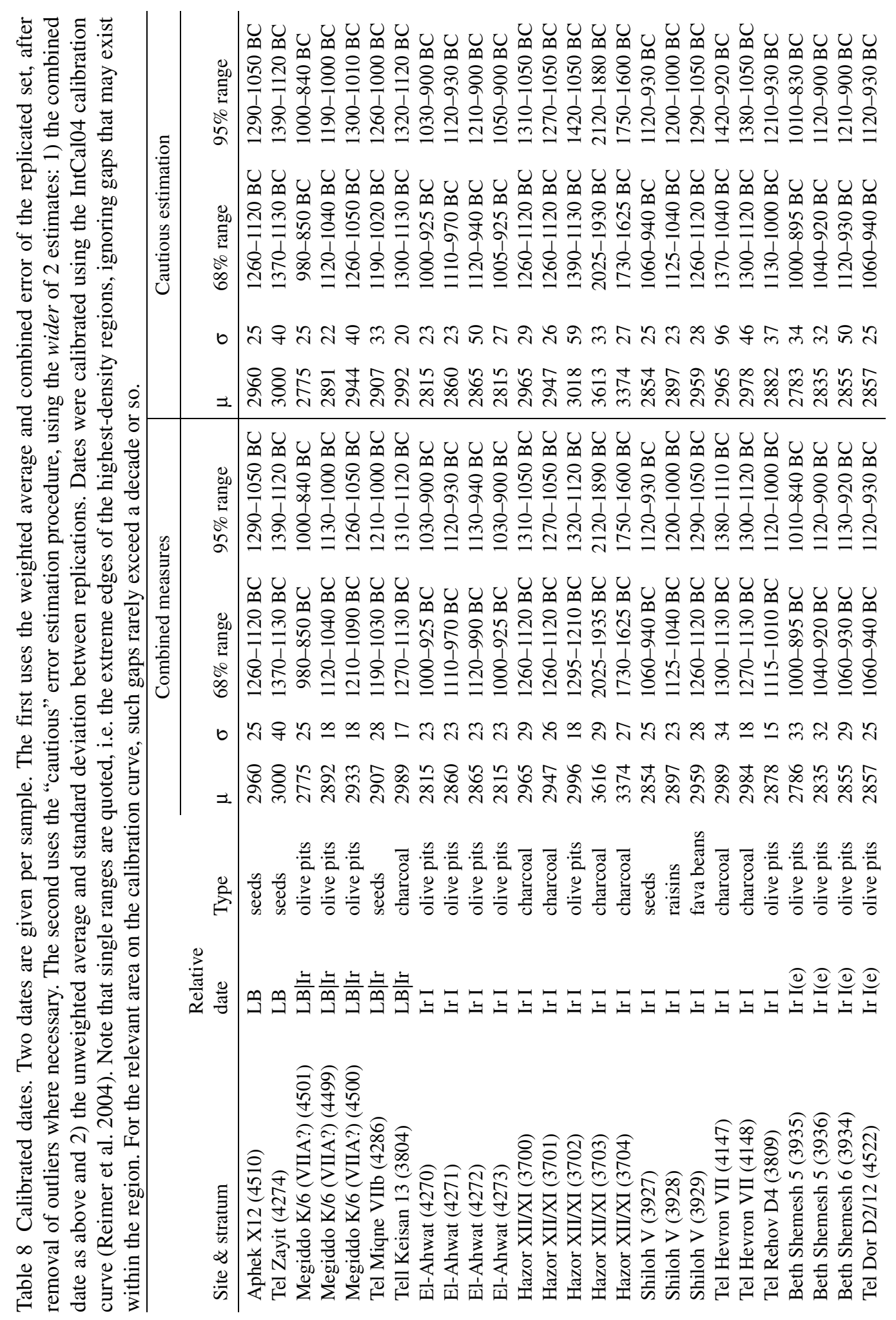




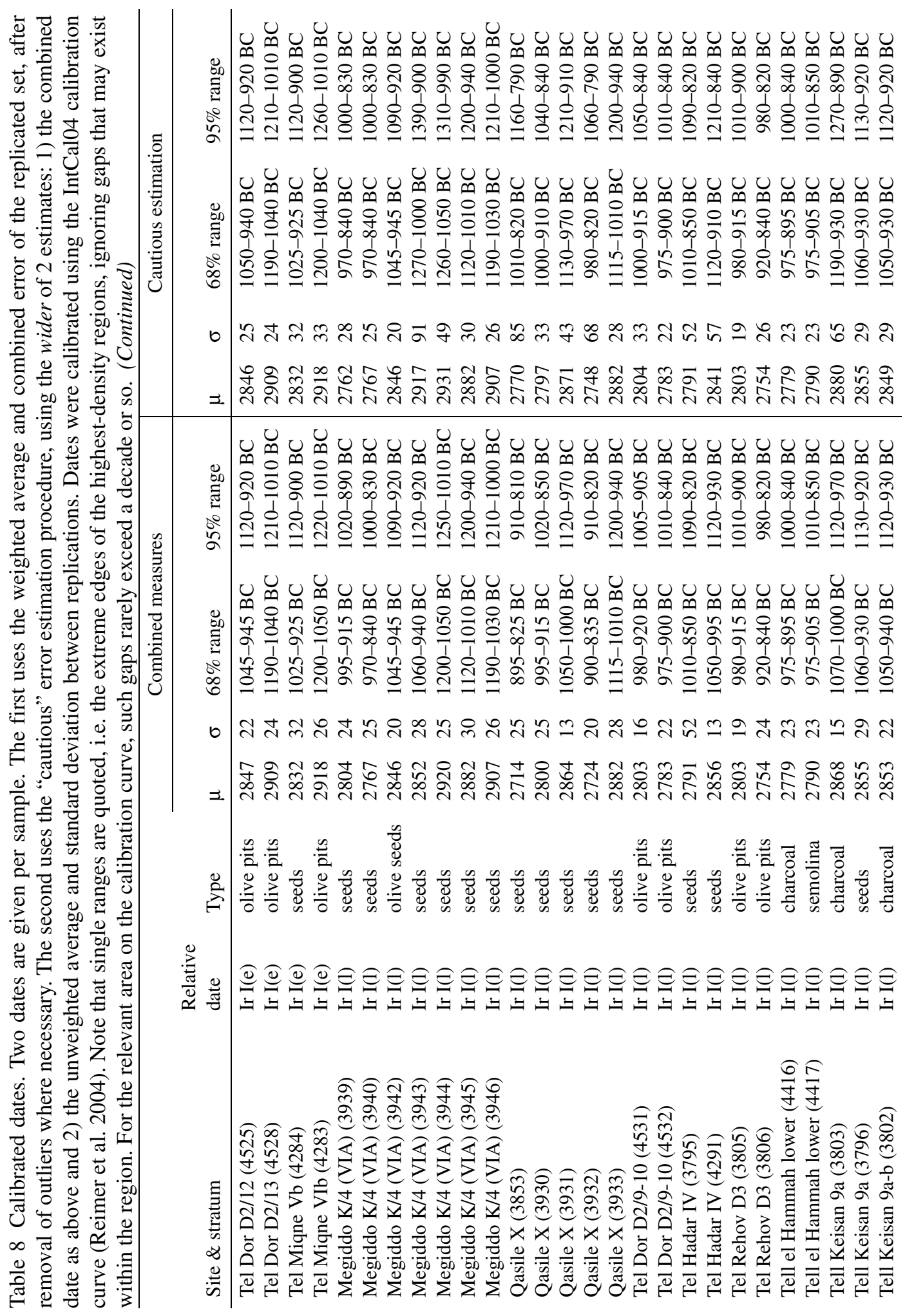




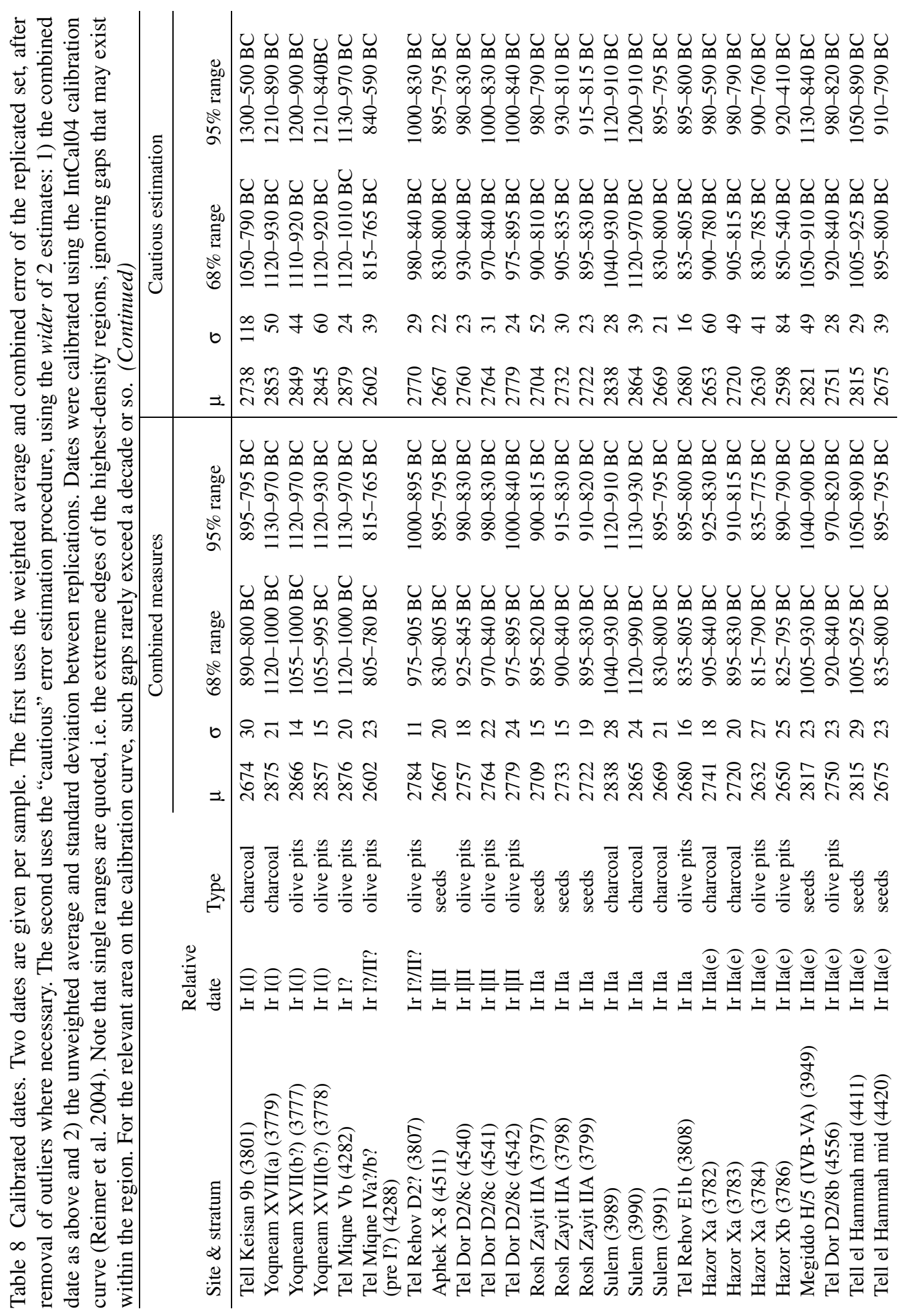




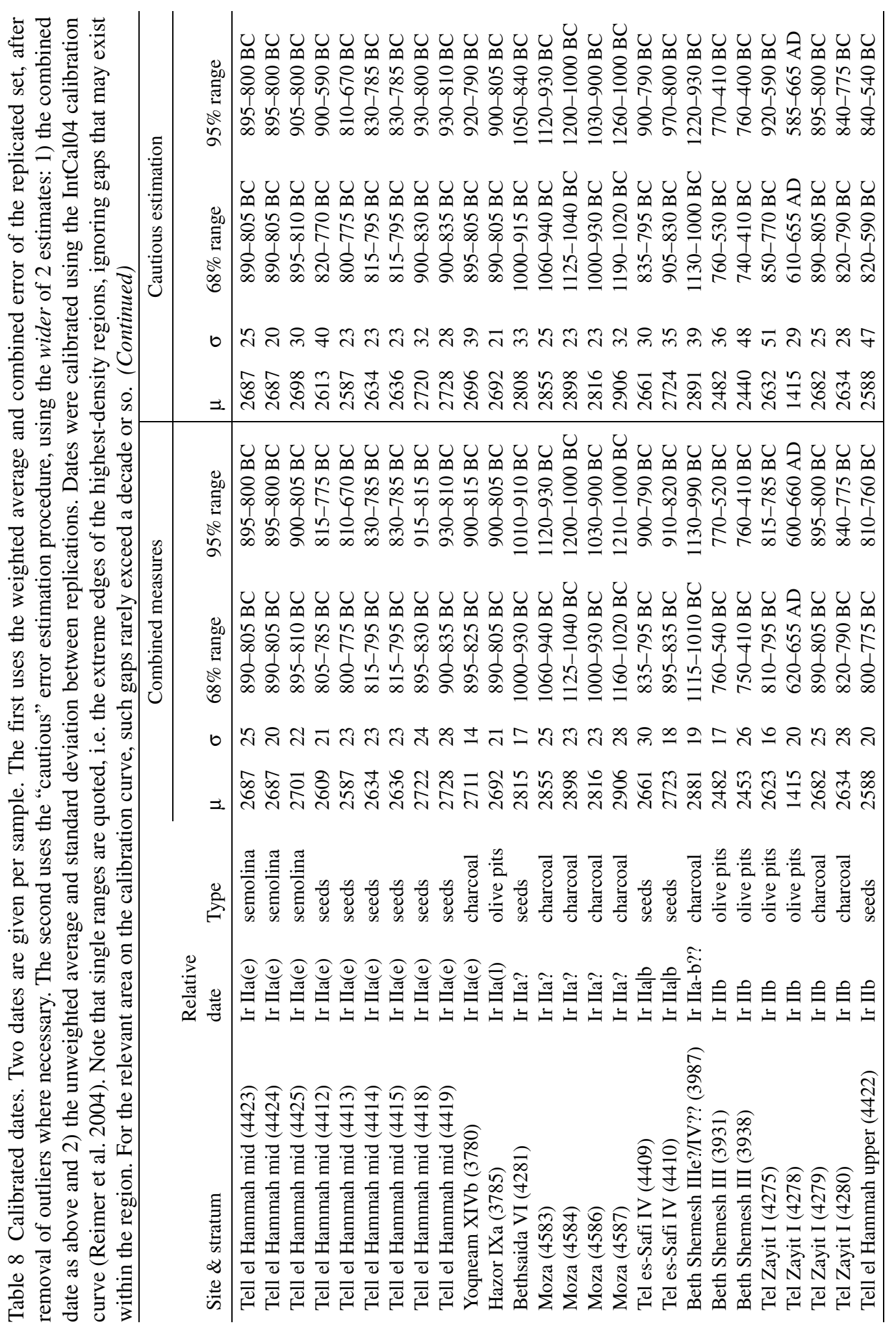




\section{REFERENCES}

Alon D, Mintz G, Cohen I, Weiner S, Boaretto E. 2002. The use of Raman spectroscopy to monitor the removal of humic substances from charcoal: quality control for ${ }^{14} \mathrm{C}$ dating of charcoal. Radiocarbon 44(1): $1-11$.

Anderson WP. 1990. The beginnings of Phoenician pottery: vessel shape, style, and ceramic technology in the early phases of the Phoenician Iron Age. Bulletin of the American Schools of Oriental Research 279:3555.

Ben-Shlomo D, Shai I, Maeir AM. 2004. Late Philistine decorated ware ("Ashdod ware"): typology, chronology, and production centers. Bulletin of the American Schools of Oriental Research 335:1-35.

Ben-Tor A, Zarzecki-Peleg A. Forthcoming. The pottery of Iron IIA-IIB in the northern valleys and Upper Galilee. In: Gitin S, editor. The Pottery of Ancient Israel and Its Neighbors from the Neolithic Through the Hellenistic Period. Jerusalem: Israel Exploration Society.

Bevington PR, Robinson DK. 1992. Data Reduction and Error Analysis for the Physical Sciences. Boston: WCB/McGraw-Hill. 384 p.

Boaretto A, Jull AJT, Gilboa A, Sharon I. 2005. Dating the Iron Age I/II transition in Israel: first intercomparison results. Radiocarbon 47(1):39-55.

Botto M. 2004. Per una riconsiderazione della cronologia degli inizi della colonizzazione fenicia nel Mediterraneo centro-occidentale. Mediterranea 1:579-630. In Italian.

Bronk Ramsey C. 2001. Development of the radiocarbon calibration program OxCal. Radiocarbon 43(2A): 355-63.

Bronk Ramsey C. 2005. Improving the resolution of radiocarbon dating by statistical analysis. In: Levy $\mathrm{T}$, Higham T, editors. The Bible and Radiocarbon Dating: Archaeology, Text and Science. London: Equinox. p 57-64.

Bruins HJ, van der Plicht J, Mazar A. 2003. ${ }^{14} \mathrm{C}$ dates from Tel Rehov: Iron-Age chronology, pharaohs and Hebrew kings. Science 300(5617):315-8.

Bruins HJ, van der Plicht J, Mazar A, Bronk Ramsey C, Manning SW. 2005. The Groningen radiocarbon series from Tel Rehov. In: Levy T, Higham T, editors. The Bible and Radiocarbon Dating: Archaeology, Text and Science. London: Equinox. p 271-93.

Coldstream JN. 1999. On chronology: the CG II mystery and its sequel. In: Iacovou M, Michaelides D, editors. Cyprus: The Historicity of the Geometric Horizon. Nicosia: University of Cyprus. p 109-18.

Coldstream JN. 2003. Some Aegean reactions to the chronological debate in the southern Levant. Tel Aviv 30:247-58.

D'Agata AL, Goren Y, Mommsen H, Schwedt A, YasurLandau A. 2005. Imported pottery of LH IIIC style from Israel. Style, provenance, and chronology. In: Laffineur R, Greco E, editors. Aegeum 25, Emporia, Aegeans in the Central and Eastern Mediterranean.
Proceedings of the 10th international conference. Athens, Italian School of Archaeology, 14-18 April 2004, Université de Liege. p 371-9.

Dothan T. 1982. The Philistines and Their Material Culture. Jerusalem: Israel Exploration Society. 352 p.

Dothan T, Zukerman A. 2004. A preliminary study of the Myc IIIC:1 pottery assemblages from Tel MiqneEkron and Ashdod. Bulletin of the American Schools of Oriental Research 333:1-54.

Fantalkin A. 2001. Low Chronology and the Greek Protogeometric and Geometric pottery in the southern Levant. Levant 33:117-25.

Finkelstein I. 1996. The archaeology of the United Monarchy: an alternative view. Levant 27:177-87.

Finkelstein I. 2000. The Philistine settlements: when, how and how many. In: The Philistines and Their World: A Reassessment. University Museum Monograph 108, University Symposium Series 11. Philadelphia: University of Pennsylvania Museum. p 159-80.

Finkelstein I, Silberman NA. 2001. The Bible Unearthed: Archaeology's New Vision of Ancient Israel and the Origin of Its Sacred Texts. New York: Free Press. 400 p.

Finkelstein I, Silberman NA. 2006. David and Solomon: In Search of the Bible's Sacred Kings and the Roots of the Western Tradition. New York: Free Press. 352 p.

Finkelstein I, Piasetzky E. 2003. Wrong and right; high and low: ${ }^{14} \mathrm{C}$ dates from Tel Rehov and Iron Age chronology. Tel Aviv 30:283-95

Finkelstein I. 2005. A Low Chronology update: archaeology, history and the Bible. In: Levy T, Higham T, editors. The Bible and Radiocarbon Dating: Archaeology, Text and Science. London: Equinox. p 31-42.

Gilboa A. 1999a. The dynamics of Phoenician Bichrome pottery. Bulletin of the American Schools of Oriental Research 316:1-21.

Gilboa A. 1999b. The view from the east-Tel Dor and the earliest Cypro-Geometric exports to the Levant. In: Iacovou M, Michaelides D, editors. Cyprus: The Historicity of the Geometric Horizon. Nicosia: University of Cyprus.

Gilboa A, Sharon I. 2001. Early Iron Age radiometric dates from Tel Dor: preliminary implications for Phoenicia, and beyond. Radiocarbon 43(3):1343-51.

Gilboa A, Sharon I. 2003. An archaeological contribution to the early Iron Age chronological debate: alternative chronologies for Phoenicia and their effects on the Levant, Cyprus and Greece. Bulletin of the American Schools of Oriental Research 332:7-80.

Herzog Z, Singer-Avitz L. 2004. Redefining the centre: the emergence of state in Judah. Tel Aviv 31:209-44.

Holden C. 2003. Dates boost conventional wisdom about Solomon's splendor. Science 300(5617):229-31.

Iacovou M. 1999. Excerpta Cypria geometrica-materials for the history of Geometric Cyprus. In: Iacovou M, Michaelides D, editors. Cyprus: The Historicity of the Geometric Horizon. Nicosia: University of $\mathrm{Cy}-$ 
prus. p 141-61.

James PJ, Thorpe IJ, Kokkinos N, Morkot R, Frankish J. 1992. Centuries of Darkness: A Challenge to the Chronology of Old World Archaeology. London: Jonathan Cape. $434 \mathrm{p}$.

Knoppers G, McConville JG, editors. 2000. Reconsidering Israel and Judah: Recent Studies on the Deuteronomistic History. Winona Lake: Eisenbrauns.

Kopcke G. 2002. 1000 B.C.E.? 900 B.C.E.? A Greek vase from Lake Galilee. In: Ehrenberg E, editor. Leaving No Stones Unturned: Essays on the Ancient Near East and Egypt in Honor of Donald P. Hansen. Winona Lake: Eisenbrauns. p 109-17.

Maeir AM. 2004. Philistine culture in transition: the transformation of Philistine culture as a process of "Creolization." Paper presented at the 4th International Congress on the Archaeology of the Ancient Near East. 1-7 April 2004, Berlin.

Manning SW, Weninger B, South AK, Kling B, Kuniholm, PI, Muhly JD, Hadjisavvas S, Sewell DA, Cadogan G. 2001. Absolute age range of the Late Cypriot IIC period on Cyprus. Antiquity 75(288):328-40.

Manning SW, Bronk Ramsey C, Kutschera W, Higham T, Kromer B, Steier P, Wild EM. 2006. Chronology for the Aegean Late Bronze Age 1700-1400 B.C. Science 312(5773):565-9.

Mazar A. 1990. Archaeology of the Land of the Bible 10,000-586 B.C.E. New York: Doubleday. 572 p.

Mazar A. 2004. Greek and Levantine Iron Age chronology: a rejoinder. Israel Exploration Journal 54:24-36.

Mazar A. 2005. The debate over the chronology of the Iron Age. In: Levy T, Higham T, editors. The Bible and Radiocarbon Dating: Archaeology, Text and Science. London: Equinox. p 15-30.

Mazar A, Bruins HJ, Panitz-Cohen N, van der Plicht J. 2005. Ladder of time at Tel Rehov: stratigraphy, archaeological context, pottery and radiocarbon dates. In: Levy T, Higham T, editors. The Bible and Radiocarbon Dating: Archaeology, Text and Science. London: Equinox. p 195-255.

Mederos Martín A. 2005. La cronología fenicia entre el Mediterráneo oriental y el occidental. Anejos del Archivo Español de Arqueología 33:305-46. In Spanish.

Nijboer AJ, van der Plicht J, Bietti Sestieri AM, de Santis A. 2001. A high chronology for the early Iron Age in central Italy. Palaeohistoria 41/42:163-76.

Reimer PJ, Baillie MGL, Bard E, Bayliss A, Beck JW, Bertrand C, Blackwell PG, Buck CE, Burr G, Cutler KB, Damon PE, Edwards RL, Fairbanks RG, Friedrich M, Guilderson TP, Hughen KA, Kromer B, McCormac FG, Manning S, Bronk Ramsey C, Reimer RW, Remmele S, Southon JR, Stuiver M, Talamo S, Taylor FW, van der Plicht J, Weyhenmeyer CE. 2004 IntCal04 terrestrial radiocarbon age calibration, $0-26$ cal kyr BP. Radiocarbon 46(3):1029-58.

Renfrew C. 1992. Foreword. In: James PJ, Thorpe IJ,
Kokkinos N, Morkot R, Frankish J, editors. Centuries of Darkness. London: Jonathan Cape. p xiii-xv.

Schreiber N. 2003. The Cypro-Phoenician Pottery of the Iron Age. Boston: Brill Academic Publishers. 384 p.

Scott EM. 2003. The Fourth International Radiocarbon Intercomparison (FIRI). Radiocarbon 45(2):35-150.

Sharon I. 2001. "Transition dating"- - a heuristic mathematical approach to the collation of ${ }^{14} \mathrm{C}$ dates from stratified sequences. Radiocarbon 43(2A):345-54.

Sharon I, Gilboa A, Jull AJT, Boaretto E. 2005. The Early Iron Age Dating Project: introduction, methodology, progress report and an update on the Tel Dor radiometric dates. In: Levy T, Higham T, editors. The Bible and Radiocarbon Dating: Archaeology, Text and Science London: Equinox. p 65-92.

Sharon I, Gilboa A, Boaretto E. Forthcoming. ${ }^{14} \mathrm{C}$ and the early Iron Age of Israel - Where are we really at? A commentary on the Tel Rehov radiometric dates. In: Bietak M, editor. The Synchronisation of Civilizations in the Eastern Mediterranean in the Second Millennium B.C. Proceedings of the 2 nd EuroConference of SCIEM 2000. 28 May-1 June 2003. Vienna: Österreichischen Akademie der Wissenschaften.

Stone BJ. 1995. The Philistines and acculturation: culture change and ethnic continuity in the Iron Age. Bulletin of the American Schools of Oriental Research 298:732 .

Thompson TL. 1999. The Mythic Past: Biblical Archaeology and the Myth of History. New York: Basic Books. $436 \mathrm{p}$

Torres Ortiz M. 1998. La cronología absoluta Europea y el inicio de la colonización fenicia en occidente: implicaciones cronológicas en chypre y el próximo oriente. Complutum 9:49-60. In Spanish.

Ussishkin D. 1985. Levels VII and VI at Tel Lachish and the end of the Late Bronze Age in Canaan. In: Tubb $\mathrm{JN}$, editor. Palestine in the Late Bronze Age. Papers in Honour of Olga Tufnell. London: Institute of Archaeology. p 213-30.

Ward WA. 1992. The present status of Egyptian chronology. Bulletin of the American Schools of Oriental Research 288:53-66.

Ward WA, Joukowsky MS, Astrom P, editors. 1992. The Crisis Years: The 12th century B.C. from Beyond the Danube to the Tigris. Dubuque, Iowa: Kendall-Hunt. $224 \mathrm{p}$.

Yizhaq M, Mintz G, Cohen I, Khalaily H, Weiner S, Boaretto E. 2005. Quality controlled radiocarbon dating of bones and charcoal from the early Pre-Pottery Neolithic B (PPNB) of Motza (Israel). Radiocarbon 47(2):193-206.

Zarzecki-Peleg A. 2005. Trajectories of Iron Age settlement in north Israel and their implications for chronology. In: Levy T, Higham T, editors. The Bible and Radiocarbon Dating: Archaeology, Text and Science. London: Equinox. p 367-78. 